Review

\title{
Arsenic Contamination of Groundwater and Its Implications for Drinking Water Quality and Human Health in Under-Developed Countries and Remote Communities-A Review
}

\author{
Samuel B. Adeloju ${ }^{1,2, *}$, Shahnoor Khan ${ }^{1,3}$ and Antonio F. Patti ${ }^{1}$ (D) \\ 1 School of Chemistry, Monash University, Clayton, VIC 3800, Australia; \\ shahnoor.khan.monash@gmail.com (S.K.); tony.patti@monash.edu (A.F.P.) \\ 2 Faculty of Science, Charles Sturt University, Albury, NSW 2640, Australia \\ 3 Ministry of Public Administration, Bangladesh Secretariat, Dhaka 1000, Bangladesh \\ * Correspondence: sadeloju@csu.edu.au; Tel.: +61-2-6051-9681
}

check for updates

Citation: Adeloju, S.B.; Khan, S.; Patti, A.F. Arsenic Contamination of Groundwater and Its Implications for Drinking Water Quality and Human Health in Under-Developed

Countries and Remote Communities-A Review. Appl. Sci. 2021, 11, 1926. https://doi.org/ 10.3390/app11041926

Academic Editors: Bart Van der Bruggen and Dino Musmarra

Received: 7 January 2021

Accepted: 16 February 2021

Published: 22 February 2021

Publisher's Note: MDPI stays neutral with regard to jurisdictional claims in published maps and institutional affiliations.

Copyright: (c) 2021 by the authors. Licensee MDPI, Basel, Switzerland. This article is an open access article distributed under the terms and conditions of the Creative Commons Attribution (CC BY) license (https:/ / creativecommons.org/licenses/by/ $4.0 /)$.
Featured Application: Groundwater contamination is a major global issue. A good understanding of the associated chemistry and fate of a contaminant such as arsenic in groundwater is important for minimizing or avoiding potential health, social and economic implications when used as a water source for human consumption.

Abstract: Arsenic is present naturally in many geological formations around the world and has been found to be a major source of contamination of groundwater in some countries. This form of contamination represents a serious threat to health, economic and social well-being, particularly in under-developed countries and remote communities. The chemistry of arsenic and the factors that influence the form(s) in which it may be present and its fate when introduced into the environment is discussed briefly in this review. A global overview of arsenic contamination of groundwater around the world is then discussed. As a case study, the identified and established causes of groundwater contamination by arsenic in Bangladesh is highlighted and a perspective is provided on the consequential health, agricultural, social and economic impacts. In addition, the relevant removal strategies that have been developed and can generally be used to remediate arsenic contamination are discussed. Also, the possible influence of groundwater inorganic compositions, particularly iron and phosphate, on the effectiveness of arsenic removal is discussed. Furthermore, some specific examples of the filter systems developed successfully for domestic arsenic removal from groundwater to provide required potable water for human consumption are discussed. Lastly, important considerations for further improving the performance and effectiveness of these filter systems for domestic use are outlined.

Keywords: arsenic; groundwater; contamination; water quality; domestic filter systems; health effects; treatment methods; Bangladesh

\section{Introduction}

Arsenic (As) is a chemical element which occurs naturally and is commonly present in the earth's crust [1]. It has been found in air, biota, water, soil and rocks [1,2]. In particular, arsenic present in an aqueous medium is of most concern because of its likely detrimental impact on plants, animals and humans. When present in high concentrations in drinking water, arsenic has been found to adversely affect human health [3] and this topic has been the subject of several recent reviews [4-6]. In this comprehensive review, we have additionally provided a detailed evaluation of treatment options for arsenic removal from water, with due consideration for affordable small scale technologies that can be easily implemented in developing countries such as Bangladesh, India, Nepal and Pakistan. 
Arsenic has been introduced to the environment through various natural and anthropogenic sources [7]. The primary natural source of arsenic is from As-enriched minerals [2]. Typical examples of natural sources include volcanoes and eroded arsenic bearing rocks, such as arsenopyrite $(\mathrm{FeAsS})$, lollingite $\left(\mathrm{FeAs}_{2}\right)$, orpiment $\left(\mathrm{As}_{2} \mathrm{~S}_{3}\right)$ and realgar $(\mathrm{AsS})$ [8]. Under oxidizing and reducing conditions, arsenic can be mobilized at $\mathrm{pH} 6.5-8.5[3,9]$ which is a common $\mathrm{pH}$ range in groundwater [9]. On the other hand, the common anthropogenic sources include agriculture, livestock and industrial manufacturing [10]. It is also widely used for the manufacture of glassware, industrial chemicals, copper, lead alloys and pharmaceuticals [10]. Industrial processes, such as smelting of iron ores, mining, pulp and paper production, cement manufacture, burning of fuels and wastes are known sources for the release of arsenic into the environment [8]. However, the focus of this review is on the contamination of groundwater by arsenic from predominantly natural sources.

Arsenic is a group Va element on the periodic table and is classified as a metalloid. In the environment, it exists in several oxidation states as $\mathrm{As}(3-)$ (arsine), $\mathrm{As}(0)$ (arsenic), $\mathrm{As}(3+)$ (arsenite) and $\mathrm{As}(5+)$ (arsenate) [11]. In natural waters, the common soluble arsenic species are the inorganic oxyanions of $\mathrm{As}(\mathrm{III})$ or $\mathrm{As}(\mathrm{V})$ [12]. As(III) species include $\mathrm{As}(\mathrm{OH})_{3}, \mathrm{H}_{2} \mathrm{AsO}_{3}{ }^{-}, \mathrm{HAsO}_{3}{ }^{2-}$ and $\mathrm{AsO}_{3}{ }^{3-}[13,14]$. As $(\mathrm{V})$ species are $\mathrm{AsO}_{4}{ }^{3-}, \mathrm{HAsO}_{4}{ }^{2-}$, $\mathrm{H}_{2} \mathrm{AsO}_{4}{ }^{-}$and $\mathrm{H}_{3} \mathrm{AsO}_{4}[13,14]$. Arsenic (III) forms complexes preferentially with oxides and nitrogen [14]. On the other hand, $\mathrm{As}(\mathrm{V})$ forms complexes with sulfides [14].

There are also organic arsenic species such as arseno-sugars dimethyl arsenic acid (DMAA) and monomethyl arsenic acid (MMAA) [15]. However, in drinking water treatment, these species are not of significant concern due to the limited effect they have on human health, and their ease of elimination from the body [15].

Under reducing anaerobic conditions, the dominant species are trivalent arsenic [9], while in oxygen rich aerobic conditions pentavalent species are dominant $[9,11,12]$. However, the key considerations for controlling the arsenic species present under various conditions are redox potential (Eh) and $\mathrm{pH}[9,16-18]$. Figure 1 shows that, under oxidizing conditions, $\mathrm{H}_{2} \mathrm{AsO}_{4}{ }^{-}$is the dominant arsenate species at low $\mathrm{pH}(\mathrm{pH}<6.9)$, whereas $\mathrm{HAsO}_{4}{ }^{2-}$ is the dominant arsenate species at a higher $\mathrm{pH}$, as illustrated in Figure 1c $[9,16,17]$. On the other hand, $\mathrm{H}_{3} \mathrm{AsO}_{3}{ }^{0}$ is the dominant arsenite species at $\mathrm{pH}<9.2$ when operating in reducing conditions, as illustrated in Figure $1 \mathrm{~b}$.

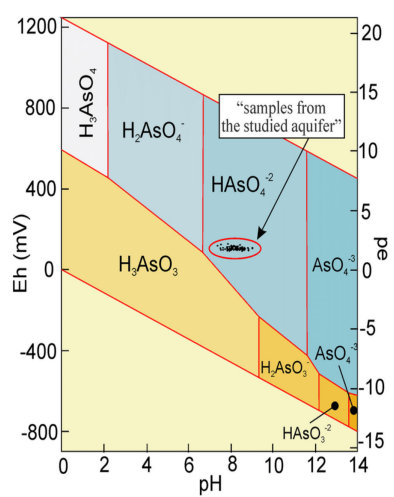

(a)

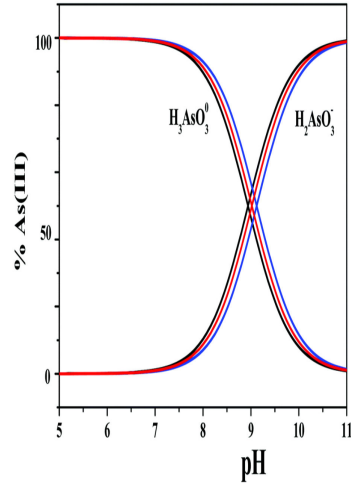

(b)

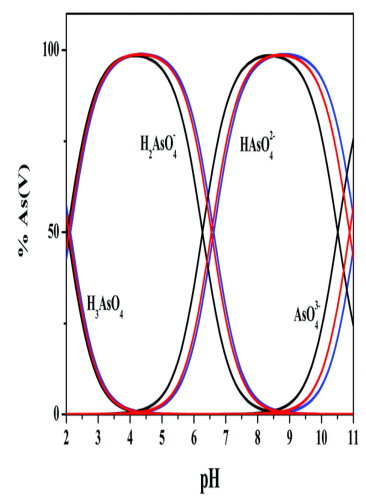

(c)

Figure 1. $\mathrm{pH}$ dependence of the aqueous speciation of $\mathrm{As}(\mathrm{III})$ and $\mathrm{As}(\mathrm{V})$ species. (a) redox potential (Eh)-pH diagram [9,17], (b) arsenite species and (c) arsenate species [16]. Operating conditions: $25^{\circ} \mathrm{C}$ and 1 bar total pressure. Reproduced with permission from Elsevier and RSC.

The presence of nitrate in groundwater has been proposed as a likely significant contributing mechanism for the oxidation of arsenic to As(V) [18]. Nitrate can act as a terminal electron acceptor and this mechanism is likely to be more prevalent under anoxic conditions. 
Reported cases of groundwater contamination by arsenic are more diverse than commonly realized and extend from under-developed to developed countries, including Argentina, Bangladesh, Canada, Chile, China, Hungary, India, Japan, Mexico, Nepal, Poland, Taiwan and the USA [15]. Figure 2 shows where groundwater or surface water contamination by arsenic has been reported. Croatia, Hungary and Serbia are three of the countries in Europe where very high concentrations of arsenic in groundwater have been reported. In Hungary, the arsenic concentrations in groundwater were found to exceed the WHO (10 $\mu \mathrm{g} / \mathrm{L})$ and EC guidelines (7.5 $\mu \mathrm{g} / \mathrm{L}$, EC Directive 2006/118/EC) by several times [19]. The concentrations of arsenic in various groundwater samples collected in Hungary and Romania ranged from $<0.5$ to $240 \mu \mathrm{g} / \mathrm{L}$ [20]. More distinctly, the highest arsenic concentrations (23 to $208 \mu \mathrm{g} / \mathrm{L}$, mean $123 \mu \mathrm{g} / \mathrm{L}$ ) were obtained in waters dominated by methanogenesis, whereas waters dominated by sulfate reduction gave lower arsenic concentrations $(<0.5$ to $58 \mu \mathrm{g} / \mathrm{L}$, mean $11.5 \mu \mathrm{g} / \mathrm{L}$ ) [20]. In Serbia, the extent of arsenic contamination is not fully resolved and yet to be determined [15]. As illustrated in Figure 2, the most affected countries in the Americas are Argentina, Chile, Mexico and the United States. In Latin America, the estimated number of people affected by arsenic contamination $>50 \mu \mathrm{g} / \mathrm{L}$ is at least four million [21]. Some wells in Argentina, Bolivia and Peru were found to contain extremely high arsenic concentrations at high $\mathrm{mg} / \mathrm{L}$ levels [21].

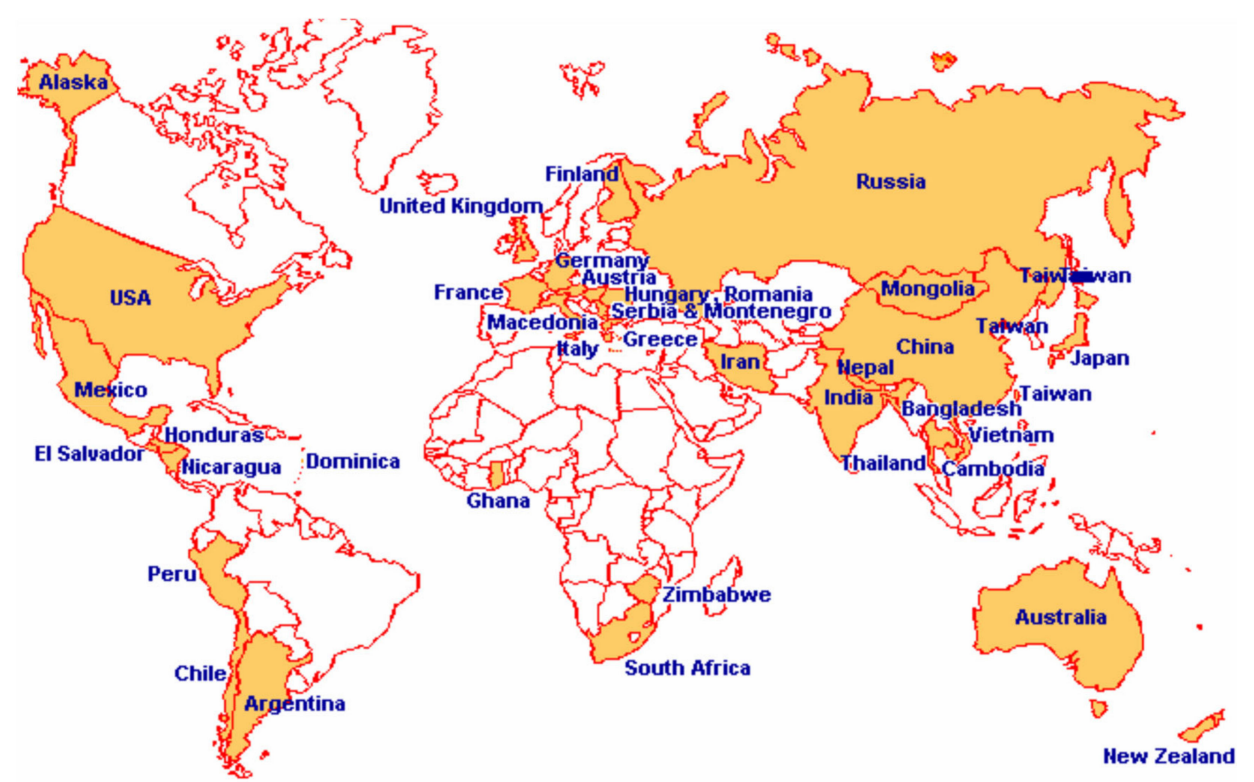

Figure 2. Countries affected by arsenic contamination of groundwater or surface waters [15]. Reproduced with permission from IJAET.

The global variation of arsenic concentrations in groundwater is summarized in Table 1. Among the affected countries, Bangladesh and West Bengal in India have the largest population at risk of exposure to arsenic contamination [7]. This is why we chose Bangladesh as a case study to highlight the extent of groundwater contamination by arsenic. The people most affected in Bangladesh and West Bengal reside where there is no access to integrated urban water supply systems, mostly in rural areas. Consequently, millions of people living in rural areas in these countries are regularly drinking water contaminated with arsenic. A relatively large number of people in this region have already been identified as having arsenic related disease symptoms [15].

UNICEF reported that 1.4 million tube wells out of the 4.75 million (around 30\%) in Bangladesh contained arsenic concentration above $50 \mu \mathrm{g} / \mathrm{L}$ [22]. A household drinking water quality survey conducted by UNICEF in Bangladesh found that $12.6 \%$ of drinking water samples exceeded the country's arsenic standard for drinking water [22]. This represents approximately 22 million Bangladesh people at risk of adverse arsenic exposure [22]. 
Furthermore, in West Bengal (India), an estimated 6 million people were found to have been exposed to relatively high arsenic concentrations, ranging from 50 to 3,200 $\mu \mathrm{g} / \mathrm{L}[23,24]$.

Table 1. Global variation of arsenic concentrations in groundwater.

\begin{tabular}{|c|c|c|c|}
\hline Country & Region & {$[\mathrm{As}], \mu \mathrm{g} / \mathrm{L}$} & Permissible Limit, $\mu \mathrm{g} / \mathrm{L}$ \\
\hline Afghanistan & Ghazni & $10-500$ & 10 (WHO) \\
\hline * Argentina & & $10-1000$ & $50(\mathrm{WHO})$ \\
\hline \# Australia & $\begin{array}{c}\text { Perth } \\
\text { Northern New South Wales } \\
\text { Victoria (Gold mining } \\
\text { regions) }\end{array}$ & $\begin{array}{c}7000 \\
52-337 \\
<1-300,000\end{array}$ & 10 (WHO) \\
\hline Bangladesh & Noakhali & $<1-4730$ & 50 (WHO) \\
\hline Brazil & $\begin{array}{c}\text { Minas Gerais } \\
\text { (Southeastern Brazil) }\end{array}$ & $0.4-350$ (Surface water) & $10(\mathrm{WHO})$ \\
\hline Cambodia & $\begin{array}{c}\text { Prey Veng and } \\
\text { Kandal-Mekong delta }\end{array}$ & Up to $9001-1610$ & $10(\mathrm{WHO})$ \\
\hline Canada & $\begin{array}{c}\text { Nova Scotia } \\
\text { (Halifax county) }\end{array}$ & $1.5-738.8$ & 10 (WHO) \\
\hline${ }^{*}$ Chile & & 900-1040 & $50(\mathrm{WHO})$ \\
\hline China & - & $50-4440$ & $50(\mathrm{WHO})$ \\
\hline * China Inner Mongolia & & $1-2400$ & 50 (WHO) \\
\hline \# Croatia (Eastern) & Osijek area & $\begin{array}{l}27 \text { (Shallow groundwater) } \\
205-240 \text { (Deep } \\
\text { groundwater) }\end{array}$ & 10 (WHO) \\
\hline Finland & Southwest Finland & 17-980 & $10(\mathrm{WHO})$ \\
\hline \# Germany & - & $10-150$ & 10 (WHO) \\
\hline \# Ghana & - & $<1-175$ & $50(\mathrm{WHO})$ \\
\hline Greece & Fairbanks (mine tailings) & Up to 10,000 & 10 (WHO) \\
\hline${ }^{*}$ Hungary & Pannonian Basin & $\begin{array}{l}10-176 \\
0.5-240\end{array}$ & $10(\mathrm{WHO})$ \\
\hline India & $\begin{array}{l}\text { West Bengal } \\
\text { Uttar Pradesh }\end{array}$ & $10-3200$ & $50(\mathrm{WHO})$ \\
\hline Italy & $\begin{array}{l}\text { Volcano island and } \\
\text { Phlegrean Fields }\end{array}$ & $0.1-6940$ & 10 (WHO) \\
\hline Japan & $\begin{array}{l}\text { Fukuoka Prefecture } \\
\text { (southern region) }\end{array}$ & $1-293$ & 10 (WHO) \\
\hline \# Lao PDR & Laos & 277.8 & 50 (WHO) \\
\hline Mexico & Lagunera & $8-620$ & 25 \\
\hline Nepal & Rupandehi & Up to 2620 & 50 \\
\hline \# New Zealand & Taupo Volcanic zone & 21 & 10 (WHO) \\
\hline Pakistan & $\begin{array}{c}\text { Muzaffargarh } \\
\text { (southwestern Punjab) }\end{array}$ & Up to 906 & 50 \\
\hline * Peru & & 500 & $50(\mathrm{WHO})$ \\
\hline * Romania & & $10-176$ & $10(\mathrm{WHO})$ \\
\hline \# Slovakia & Banska Bystrica and Nitra & $37-39$ & 10 (WHO) \\
\hline \# Spain & - & $<1-100$ & $10(\mathrm{WHO})$ \\
\hline Taiwan & - & $10-1820$ & $10(\mathrm{WHO})$ \\
\hline Thailand & Ron Phibun & $1->5000$ & 10 (WHO) \\
\hline \# UK & Southwest England & $<1-80$ & $10(\mathrm{WHO})$ \\
\hline USA & Tulare Lake & Up to 2600 & 10 (USEPA) \\
\hline Vietnam & $\begin{array}{l}\text { Red River Delta } \\
\text { (North Vietnam) } \\
\text { Mekong Delta } \\
\text { (South Vietnam) }\end{array}$ & $<1-3050$ & 10 (WHO) \\
\hline
\end{tabular}

Adapted and modified from [3], * [15] and \# [25].

Usually after a few years of extraction of groundwater, a considerable increase in the concentration of arsenic in wells has been observed [15]. Future increases in arsenic contamination issues in drinking water are expected despite the establishment of a stringent 
standard for arsenic in drinking water and this may spread to other countries [15]. Due to the greater risk that arsenic contamination of groundwater poses to the Bangladeshi people, it is useful to take a closer look at the widespread nature of the problem in this country.

\section{Case Study-Arsenic Contamination of Groundwater in Bangladesh}

\subsection{Background}

Bangladesh is a tropical country with a total area of about $147,570 \mathrm{~km}^{2}$ and an estimated population of 160 million as of 2016 [26]. About $58 \%$ of the surface area is arable land and about $11 \%$ comprises forests and woodlands. The contribution of the agricultural sector to national GDP (Gross Domestic Product) is about 18\%, while about $72 \%$ of its people are based in rural settings [26]. The per capita income in 2015-2016 is US\$ 1466 [26].

Although there is abundant groundwater in Bangladesh and the productivity of the aquifers are very high, variable water tables are observed in different parts of the country, more commonly shallow and below the ground surface by 1-10 $\mathrm{m}$ [27]. Groundwater is generally free from pathogenic microorganisms and, if not contaminated, can be reasonably safe to use. For these reasons groundwater has remained an appealing and readily available reserve for drinking water in many countries [27]. This has resulted in the widespread use of groundwater as the main source of drinking water, particularly as tube wells for the past forty years or more. The tube wells have contributed significantly to the reduction of mortality rate of diarrheal diseases [28]. Bangladesh achieved a remarkable success by providing $97 \%$ of the rural population with tube well water [28].

However, the coverage for safe drinking water has been significantly reduced from $97 \%$ to $74 \%$ as a consequence of the extensive contamination of groundwater with arsenic [28]. Consequently, the mortality rate in Bangladesh was increased as a result of arsenic contamination of the drinking water [29]. About $12.6 \%$ of its population are still accessing this contaminated water [22]. This has led to the recognition of arsenic contamination as a catastrophic issue in Bangladesh [22]. To understand the cause of this problem, a knowledge of the geological characteristics of Bangladesh is useful.

\subsection{Geology of Bangladesh}

Young (Holocene) alluvial and deltaic sediments dominate the geology of Bangladesh. The major river systems of the Bengal Basin are responsible for the deposition of these sediments [27]. Most of these sediments, of several hundreds of meters in thickness, have been deposited within the last 6000-10,000 years [27]. The Basin is now recognized in the world among the most rapidly developed delta systems [27]. In the north, the surface sediments consist mainly of coarse-grained mountain-front alluvial fan deposits, while alluvial sands and silts represent the main composition of sediments from central Bangladesh. The predominant composition of the sediments in the south are deltaic silts and clays. On approaching the southern part of Bangladesh, the deposits tended to be increasingly fine-grained [27]. Figure 3 illustrates the surface geological units of Bangladesh. Evidently, the surface geological characteristics are very diverse in nature.

\subsection{Mobilization of Arsenic in Groundwater in Bangladesh}

The two most widely discussed hypotheses for the sources of arsenic contamination of groundwater in Bangladesh are the pyrite oxidation hypothesis and the iron oxyhydroxide reduction hypothesis [6,30].

The "Barind and Modhupur Tracts" made up of up-faulted terraces of older (Pleistocene) sediments are the key characteristics of the surface geology in north-central Bangladesh. Unlike the surrounding alluvium deposits, these sediments have experienced significantly more weathering [27]. The younger alluvial sediments in these tracts are present at depths ranging or greater than 50-200 m. However, for the older sediments, the extent of its distribution is still relatively unknown [27]. In south-east Bangladesh, older (Tertiary) sediments dominate the geology of the Chittagong Hill Tracts and their main composition are sandstone, silt and limestone [27]. Within $20-80 \mathrm{~m}$ depth, the 
sediment was found to be very rich in arsenopyrite [31]. The granitic and metamorphic processes of the Himalayas was the original source of the sediment [31]. After the introduction of the sediment into the Ganges delta, it became part of the aquifers [31]. Additional arsenic is retained as an adsorbed coating with ferric oxy-hydroxide on the sediments [32]. It is understood that the transport and deposition of arsenic and ferric oxy-hydroxide in the Ganges delta along with abundant organic matter resulted from the oxidation of arsenopyrite $[33,34]$. Figure 4 illustrates the arsenic contaminated areas in Bangladesh [24]. Obviously, the arsenic concentrations present in many areas are considerably above $50 \mu \mathrm{g} / \mathrm{L}$.

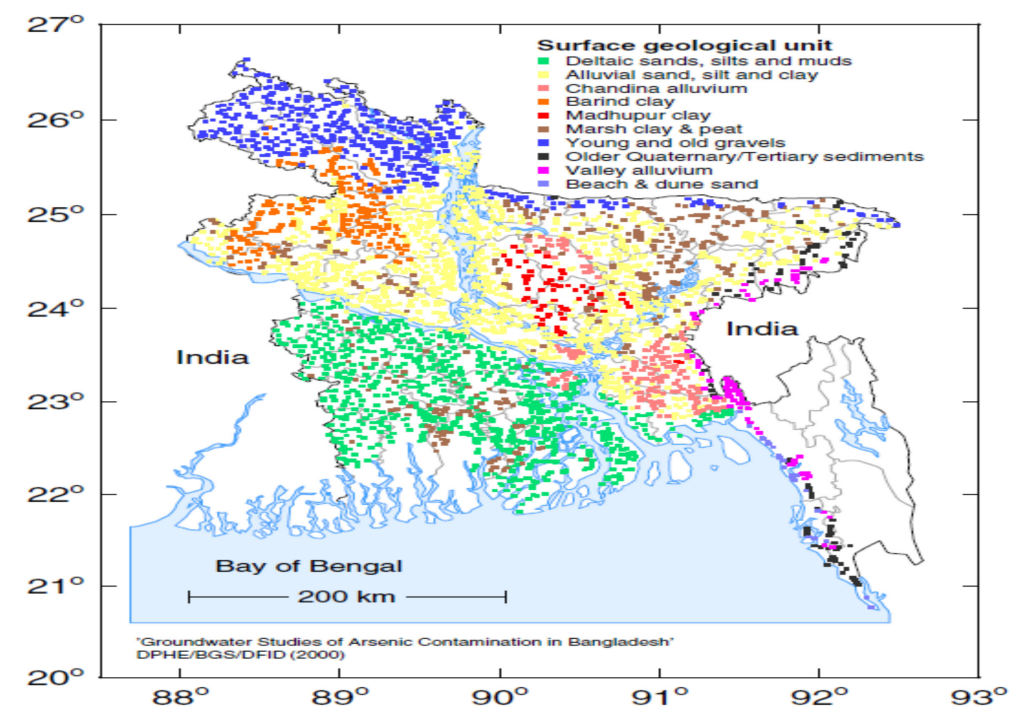

Figure 3. Surface geological units of Bangladesh [27]. Reproduced with permission from BGS.

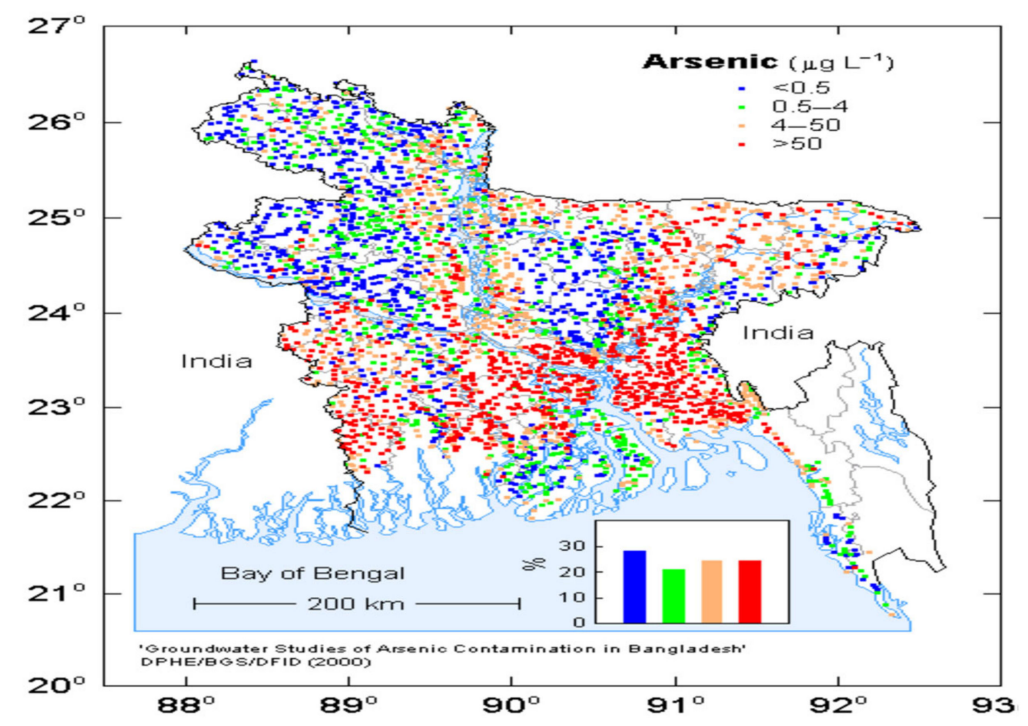

Figure 4. Arsenic contaminated areas in Bangladesh [24]. Reproduced with permission from BGS.

\subsubsection{Pyrite Oxidation Hypothesis}

Studies have shown that there is a high level of arsenopyrite (FeAsS) in the alluvial regions of Bangladesh $[31,35]$. The basis of the pyrite oxidation hypothesis is that the oxidation of arsenopyrite resulted in the release of arsenic into groundwater [36-39]. This process is understood to be aided by the invasion of the aquifers by atmospheric oxygen when the water table is lower than these deposits, resulting in its diffusion into 
the pore space and groundwater. Consequently, the reaction between the arsenopyrite and available oxygen resulted in a water-soluble form of arsenic which was consequently released into the groundwater [30].

The associated reactions for this process are:

$$
\begin{aligned}
& 4 \mathrm{FeAsS}+11 \mathrm{O}_{2}+6 \mathrm{H}_{2} \mathrm{O} \rightarrow 4 \mathrm{FeSO}_{4}+4 \mathrm{H}_{2} \mathrm{AsO}_{3}{ }^{-}+4 \mathrm{H}^{+} \\
& 4 \mathrm{FeAsS}+13 \mathrm{O}_{2}+6 \mathrm{H}_{2} \mathrm{O} \rightarrow 4 \mathrm{FeSO}_{4}+4 \mathrm{H}_{2} \mathrm{AsO}_{4}{ }^{-}+4 \mathrm{H}^{+}
\end{aligned}
$$

The above hypothesis is supported by the absence of arsenic-affected people before irrigation became more intensive at the beginning of the 1980s. Consequently, the total irrigated area which used groundwater increased significantly from $41 \%$ to $71 \%$ within $1982 / 1983$ and 1996/1997, respectively, while in the same period the use of surface water decreased considerably from $59 \%$ to $29 \%$ [30].

Based on the pyrite oxidation hypothesis, the lowering of the water table resulted from the considerable use of groundwater, and, in turn, led to groundwater contamination with arsenic. The arsenic mobilization proposed by this hypothesis is widely accepted as the main mechanism for intrusion of arsenic into groundwater in Bangladesh [36,40,41]. However, the hypothesis is not yet fully validated as there is a need for further hydrological and geochemical data [42].

\subsubsection{Iron Oxyhydroxide Reduction Hypothesis}

Another suggestion proposed as the source of groundwater contamination with arsenic in Bangladesh is based on the so-called iron oxyhydroxide reduction hypothesis. This hypothesis is based on the premise that the source of arsenic was from the Ganges region, upstream of Bangladesh, where arsenic sulfide minerals followed by abrasion were carried by water about 1.6-1.8 million to 10,000 years ago during the late Pleistocene age [43]. As these arsenic-containing minerals travelled down the Ganges, arsenic was adsorbed to iron oxyhydroxide (FeOOH). The arsenic-rich iron oxyhydroxides were deposited at the Gangetic delta, and formed an alluvial aquifer. Various processes, including burial of vegetation, agriculture and floods, led to the introduction of organic carbon into the aquifer [8]. This organic carbon provided food for bacteria and the presence of methane in the water indicates that organic matter is being utilized in the aquifer by anaerobic bacteria [30]. Consequently, the redox potential of the groundwater is lowered by this biological process. Due to this reducing environment, the iron oxyhydroxide is broken down, resulting in the introduction of adsorbed arsenic into the groundwater [36,39,43-45]. The adsorption of arsenic by hydrous iron oxyhydroxide is supported by the following reactions [8]:

$$
\begin{aligned}
& \mathrm{Fe}(\mathrm{OH})_{3}+\mathrm{H}_{3} \mathrm{AsO}_{4} \rightarrow \mathrm{FeAsO}_{4} \cdot 2 \mathrm{H}_{2} \mathrm{O}+\mathrm{H}_{2} \mathrm{O} \\
\equiv & \mathrm{FeOH}^{\mathrm{o}}+\mathrm{AsO}_{4}{ }^{3-}+3 \mathrm{H}^{+} \rightarrow \equiv \mathrm{FeH}_{2} \mathrm{AsO}_{4}+\mathrm{H}_{2} \mathrm{O} \\
\equiv & \mathrm{FeOH}^{\mathrm{o}}+\mathrm{AsO}_{4}{ }^{3-}+2 \mathrm{H}^{+} \rightarrow \equiv \mathrm{FeHAsO}_{4}{ }^{-}+\mathrm{H}_{2} \mathrm{O}
\end{aligned}
$$

The reduction of hydrous iron oxides can occur by the following reaction:

$$
\mathrm{Fe}(\mathrm{OH})_{3}+\mathrm{e}^{-} \rightarrow \mathrm{Fe}^{2+}+3 \mathrm{OH}^{-}
$$

Therefore, the presence of anoxic conditions is necessary for arsenic-rich iron oxyhydroxide to be reduced and, in turn, release arsenic. This process mobilizes iron and its adsorbed load into the groundwater. Some researchers have accepted the arsenic mobilization based on the iron oxyhydroxide reduction hypothesis as the main mechanism for groundwater contamination by arsenic in Bangladesh [27,36,42,46]. However, a more comprehensive sampling and systematic analysis of ferric oxyhydroxide in the areas affected is needed to validate the reduction hypothesis [27,42]. 
Furthermore, it may also be possible for both of the mechanisms discussed above to contribute to arsenic release. This is in view of the fact that the pyrite oxidation occurs under an oxic condition, while iron oxyhydroxide reduction occurs under an anoxic condition.

\section{Effects of Arsenic Contamination}

Groundwater contamination by arsenic in Bangladesh has had adverse effects on human health, agriculture, social well-being and the economy of the country. To highlight the seriousness of these impacts, each of these is discussed in more details below.

\subsection{Effects on Health}

Groundwater contamination by arsenic has resulted in numerous serious health consequences in Bangladesh [47-49]. Globally, arsenic contamination in drinking water has reportedly led to the exposure of about 150 million people leading to serious health effects [50]. Of these, about 110 million people live in Bangladesh, Cambodia, China, India, Laos, Myanmar, Nepal, Pakistan, Taiwan and Vietnam [51]. In addition, many people are affected through consumption of arsenic-contaminated foods produced from the use of arsenic contaminated groundwater [50,51]. It has been found that rice grains contribute about half of the daily intake of arsenic in Bangladesh [52]. A survey conducted within arsenic-affected villages in Bangladesh collected hair, nail, urine and skin-scale samples totaling more than 10,000 which were subsequently analyzed for arsenic [53]. The results of the survey indicated that the arsenic concentrations in $93.8 \%$ and $95.1 \%$ of nails and urine samples, respectively, exceeded the normal level. For nail, the acceptable arsenic concentration range is $0.43-1.08 \mathrm{mg} / \mathrm{kg}$ [54], while for urine the range is $0.005-0.04$ $\mathrm{mg}$ /day [55]. Furthermore, $83.2 \%$ and $97.4 \%$ of hair and skin-scale samples, respectively, gave arsenic contents that far exceeded the toxic level of $1 \mathrm{mg} / \mathrm{kg}$ [56]. These results therefore revealed a serious impact on health that has arisen from human exposure to arsenic through groundwater contamination in Bangladesh.

A recent comprehensive overview on the adverse effects from inorganic arsenic exposure details the major health issues [57]. Carcinogenic effects are particularly prevalent and the most common consequences resulting from poisoning from drinking arsenic contaminated water are skin diseases, including hyperkeratosis, keratosis, leuco-melanosis and melanosis (hyper pigmentation) [57-64]. Arsenicosis is initially manifested by melanosis which usually occurs all over the body [57,62]. The hardening of the melanosis spots leads to the commencement of keratosis [62]. A long-term exposure to arsenic results in the hyperkeratosis of the palms and soles [59]. Other associated health effects resulting from ingestion of arsenic include cardiac failure, chromosomal abnormality, cirrhosis, diabetes mellitus, gangrene, goiter, hypertension (high blood pressure), liver enlargement, myocardial degeneration, peripheral neuropathy and skin cancers $[59,62,63]$.

Also, the development of cognitive and psychological functions in children has been shown to be affected by extended consumption of arsenic contaminated drinking water [65]. Furthermore, areas where highly contaminated groundwater is used have been shown to be more prone to higher fetal loss and infant deaths [66].

\subsection{Effects on Agriculture}

Groundwater is the main source of water used for agriculture in Bangladesh. Consequently, when contaminated with arsenic, it can result in the introduction of arsenic into agricultural soils and crops, such as rice and vegetables $[51,67,68]$. For the same reason, it has also been found in many areas in Bangladesh that high arsenic concentrations are present in the agricultural soils and the usage of groundwater contaminated with arsenic for irrigation has been identified as the main cause [50,52].

A main consequence is the dual arsenic accumulation in vegetables and rice grains from both soils and irrigation water [30,50,51,69-71]. More seriously, the phytotoxic effects of arsenic can result in a significant reduction of crop yields [52]. The variation of arsenic contents of selected foods from different countries is demonstrated by the data 
in Table 2. In general, arsenic concentrations in these foods are lowest when obtained in countries with little or no exposure to arsenic contamination of water source.

Rice, which is a staple part of the diet in Bangladesh, has been extensively studied in the context of mitigating and reducing the uptake of arsenic during its cultivation. An excellent review on this topic has been recently published [72]. The authors have indicated that by employing water management, physico-chemical and biological strategies, either alone or combined, the uptake of inorganic and methylated arsenic species in rice cultivation can be successfully decreased. These approaches may also be adapted for other crops. The adoption of these strategies is a major challenge for countries like Bangladesh, where socio-economic factors can be a hindrance.

Table 2. Concentrations of arsenic in selected foods from different countries.

\begin{tabular}{|c|c|c|c|c|}
\hline Country & $\begin{array}{l}\text { Vegetables } \\
(\mu \mathrm{g} / \mathrm{kg})\end{array}$ & Rice $(\mu \mathrm{g} / \mathrm{kg})$ & $\begin{array}{l}\text { Fish/Shrimp } \\
(\mu \mathrm{g} / \mathrm{kg})\end{array}$ & $\begin{array}{l}\text { Other Foods } \\
\quad(\mu \mathrm{g} / \mathrm{kg})\end{array}$ \\
\hline Australia & & $30(20-40)$ & & \\
\hline Bangladesh & $54.5(<5-540)$ & $500(30-1840)$ & $(97-1318)$ & $\begin{array}{c}45.9(44.9-46.9) \\
\text { Betel leaf }\end{array}$ \\
\hline Bangladesh $^{\mathrm{a}}$ & $(70-3990)$ & $496(58-1830)$ & & \\
\hline Bangladesh $^{b}$ & & & $(214-266)$ & \\
\hline China & & $140(20-460)$ & & \\
\hline China $^{a}$ & & 930 & & \\
\hline Europe & $(<5-87)$ & & & \\
\hline United Kingdom & $\begin{array}{c}2 \text { (green veg) } \\
4.9 \text { (other veg) }\end{array}$ & & & \\
\hline USA & & $250(30-660)$ & & \\
\hline $\begin{array}{l}\text { West Bengal } \\
\text { (India) }\end{array}$ & & $140(20-400)$ & & \\
\hline $\begin{array}{l}\text { West Bengal } \\
\text { (India) }^{\mathrm{a}}\end{array}$ & & $\begin{array}{c}250(140-480) 330 \\
(180-430)\end{array}$ & & \\
\hline
\end{tabular}

\subsection{Social Effects}

The prevalence of arsenic poisoning has triggered many social implications [48,49,74,75]. Relatives, friends and neighbors often ostracize the people affected by arsenic poisoning. There is a general tendency to avoid or discourage the arsenic-affected people from being seen in public. More concerning, school attendance by their children is usually prohibited, while attendance at work places and public meetings is not encouraged for the adults [76].

For women, arsenic poisoning has more dire social consequences [76]. Young women who have had arsenicosis are often constrained from getting married. Even married women who have arsenic related diseases are also socially ostracized. Evidently, the males, females and children who are affected by arsenic poisoning are severely disadvantaged socially [76].

\subsection{Economic Impact}

There is a direct relationship between the economic impact of suffering from arsenicosis and the social impact experienced from the disease [48,49,74,75,77]. Usually once a family member becomes sick from arsenic poisoning, various coping mechanisms are experienced. This may involve selling of assets, reduction of basic needs, reduction of access to education and the associated burden of financial loans [76]. Consequently, a large-scale poisoning of the population can impact the nation's economy, requiring the Government, in extreme cases, to reduce its social and economic development programs as a basis for dealing with the disaster. 
Attempts to minimize or eliminate the impacts of groundwater contamination with arsenic have resulted in various strategies for arsenic removal from groundwater with a varying level of successes. Nevertheless, there is still considerable research being undertaken in this area to achieve efficient and reliable removal of arsenic from groundwater to ensure safe human consumption. Some of these removal processes and strategies are discussed below.

\section{Arsenic Removal Processes}

A major approach for reducing arsenic poisoning is by treatment of arsenic-contaminated water and the new and emerging treatment technologies have received considerable evaluation and have also been recently reviewed [47,78-80]. The major categories of treatment methods that have been used for this purpose are described below [81]:

(i) Oxidation and filtration process: This usually involves the oxidation of arsenic with inorganic iron and manganese oxides, followed by removal of the residues by filtration $[82,83]$. Due to the uncharged nature of As(III) complexes, an oxidation step is often employed to oxidize As(III) complexes to As(V) complexes [84].

(ii) Biological oxidation: Microorganisms are used in this case to oxidize As(III) to As(V), followed by $\mathrm{As}(\mathrm{V})$ removal with iron and manganese dioxide [85,86].

(iii) Co-precipitation: This involves the addition of a suitable oxidizing agent to oxidize $\mathrm{As}(\mathrm{III})$ to $\mathrm{As}(\mathrm{V})$, followed by coagulation, sedimentation and filtration $[87,88]$.

1. [(iv)] Adsorption: This approach involves the adsorption of arsenic with activated alumina, activated carbon, hydrated iron oxide, iron based adsorbents and zero valent iron [89-91].

(v) Ion exchange: This involves the use of relevant exchange resins (cation or anion) for separation of arsenic [92,93].

(vi) Membrane technology: This includes the use of processes such as electrodialysis, nanofiltration and reverse osmosis for removal of arsenic [94-98].

The following sub-sections provide more detailed discussion of some of these treatment methods.

\subsection{Biological Process}

Numerous biological treatment options for removal of metals from drinking water are available [99] and the biological treatment of groundwater for arsenic removal employs naturally occurring microorganisms, such as Gallionellaferruginea and Leptothrixochracea [100]. The addition of these organisms to the groundwater results in the formation of new iron oxide precipitates on the filter, which subsequently removes arsenic from the water by adsorption. Under optimized conditions, As(III) is oxidized by these microorganisms, enabling removal of up to $95 \%$ of arsenic from waters which contain $200 \mu \mathrm{g} / \mathrm{L}$ of arsenic [100]. This process also enabled the removal of $\mathrm{As}(\mathrm{V})$. For a comprehensive overview of biological transformations of arsenic, which includes possible detoxification mechanisms, refer to a recent review on this topic [101].

\subsection{Precipitative Processes}

This category of arsenic removal processes includes coagulation and filtration [87], coagulation-assisted microfiltration [102], enhanced coagulation [103] and lime softening [104]. These are very popular processes that require the addition of either aluminum sulfate, ferric chloride or ferric sulfate as a coagulant to change either the chemical or physical properties of dissolved colloidal or suspended matter [105]. To promote rapid settling out of the particles by gravity, the enhancement of agglomeration is used in some cases, otherwise filtration is used to remove the particles [105]. Agglomeration is usually accomplished by changing the surface charge properties of solids with coagulants to enable formation of a flocculated precipitate. The resulting products of this process are larger particles or flocs that filter or settle out more easily under gravity [106]. 
Greater than $90 \% \mathrm{As}(\mathrm{V})$ removal has been successfully achieved with coagulation processes [107]. The use of coagulation with alum, ferric chloride and ferric sulfate for removal of $\mathrm{As}(\mathrm{III})$ is far less efficient than the removal of $\mathrm{As}(\mathrm{V})$ [107]. To ensure efficient arsenic removal, $\mathrm{As}(\mathrm{III})$ is usually oxidized to $\mathrm{As}(\mathrm{V})$ prior to coagulation. Effective $\mathrm{As}(\mathrm{V})$ removal is usually accomplished at $\mathrm{pH} 7.6$ or less with iron and aluminum coagulants. However, in terms of stability, iron coagulants offer more advantage than aluminum coagulants when operating within a $\mathrm{pH}$ range of 5.5 to 8.5 [9]. The key factors that influence the choice of the optimum coagulant dose are the water quality and the arsenic concentration in the treated water. The overall cost of the water treatment process can be significantly increased if further adjustment of the $\mathrm{pH}$ is necessary to achieve a more effective removal of arsenic [106].

Some field studies have demonstrated the effectiveness of coagulation/filtration in reducing the arsenic level to below $5 \mu \mathrm{g} / \mathrm{L}$ [106]. However, under optimum operating conditions, the achievement of a residual arsenic level of less than $3 \mu \mathrm{g} / \mathrm{L}$ is possible [107].

\subsection{Membrane Processes}

Siddique et al. [108] have recently reviewed the application of nanofiltration membrane technologies and their advantages and disadvantages relative to other methods. The membrane processes used for arsenic removal mainly include reverse osmosis [94,95] and electrodialysis [96]. While these processes are effective, they are generally more costly. Nonetheless, they are capable of removing arsenic through filtration, electric repulsion, and adsorption of arsenic-bearing compounds. The size exclusion property of a chosen membrane enables rejection of arsenic compounds larger than its pore size [107]. Besides the size of the compounds, the rejection by the membrane can be influenced by other factors. In some instances, arsenic compounds that are 1-2 orders of magnitude smaller than the membrane pore size have been rejected, thus suggesting that besides physical straining, other removal mechanisms may be involved [107]. Two factors that play significant roles in arsenic rejection by a membrane are shape and chemical characteristics of the arsenic compounds. Removal of arsenic compounds on membranes can also be accomplished through repulsion or surface adsorption depending on the charge and hydrophobicity of the membrane and the feed water [109]. The achievement of removal efficiency of $97 \%$ for $\mathrm{As}(\mathrm{V})$ and $92 \%$ for $\mathrm{As}(\mathrm{III})$ in a single pass by reverse osmosis has been reported [107].

\subsubsection{Arsenic Removal by Membrane Distillation}

As a non-isothermal membrane separation process, membrane distillation (MD) utilizes a microporous hydrophobic membrane with pore size ranging from $0.01 \mu \mathrm{m}$ to $1 \mu \mathrm{m}$ [97]. For effective operation, only vapor and non-condensable gases must be present within the membrane pores and the membrane must not be wet [97,98]. Commercially available hydrophobic micro-porous membranes include polytetrafluoroethylene, polyethylene, polypropylene and polyvinylidenefluoride membranes [98]. The simplest and most economical and efficient of the different kinds of MD is direct contact membrane distillation (DCMD) $[97,98]$. DCMD directly separates the hot feed and the cold permeate with the aid of the membrane. Up to $100 \%$ of arsenic has been removed from contaminated groundwater with DCMD $[97,98]$.

\subsubsection{Membrane and Adsorption Process Hybrid}

New technologies with different processes have also been adopted for further improvement of arsenic removal [2]. Membrane technologies along with low cost adsorptive media have been shown to be effective for the removal of arsenic from water [110]. This has led to the production of a cheap, easy to operate filter system for delivering safe and arsenic-free drinking water. This system consists of three basic components: an organic membrane, a tank/drum in which the membrane is inserted and an adsorptive cartridge made of industrial waste products [110]. 


\subsection{Adsorptive Processes}

Adsorptive processes include ion exchange [94,95], iron oxide/hydroxide coated sand [89,90,111,112], iron-hydroxide coated alumina [91], granular ferric hydroxide (GFH) [113,114] and natural iron ores [115]. A desirable feature of the available adsorbents for developing countries is that they should be cheap, readily available and effective [116].

The basis of adsorption methods is the ability to achieve the attraction of soluble arsenic species to the surface of a suitable sorbent. These methods are cost-effective and have attracted a considerable interest for the development of adsorbents that are capable of cheap and efficient arsenic removal from drinking water. The two most commonly used sorbents are based on: (a) iron compounds, including akaganeite $(\beta-\mathrm{FeOOH})$, amorphous hydrous ferric oxide $(\mathrm{FeOOH})$, goethite $(\alpha-\mathrm{FeOOH})$ and poorly crystalline hydrous ferric oxide [111], and (b) aluminum compounds, including activated alumina $\gamma-\mathrm{Al}_{2} \mathrm{O}_{3}$ and gibbsite $\mathrm{Al}(\mathrm{OH})_{3}[117]$.

Among other sorbents considered are carbon from coconut husks [118], carbon from fly ash $[119,120]$, hybrid polymeric materials [121], red mud [122,123], titanium dioxide [124,125], manganese dioxide [126,127], orange peel [128] and fungal biomass-based bio-sorbent $[86,129]$.

\subsubsection{Iron Oxides/Oxyhydroxides Based Adsorbents}

The effectiveness of various iron compounds for metal ion removal has been demonstrated in a number of studies $[35,130]$. Those found to be effective sorbents for arsenic removal from aqueous solutions include $\beta-\mathrm{FeOOH}, \mathrm{FeOOH}, \alpha-\mathrm{FeOOH}$ and poorly crystalline hydrous ferric oxide $[80,90,111,112]$. Other iron oxides/oxyhydroxides-based sorbents that have been considered include Cerium (IV)-doped iron oxide adsorbent [115], GFH $[113,114]$, iron-hydroxide coated alumina [91], iron oxide-coated polymeric minerals [100,131], iron oxide-coated sand [132], magnetic iron oxide/activated carbon composite [132], iron oxide-coated cement [96], magnetically modified zeolite [90], natural iron ores [115], silica-containing iron(III) oxide [133] and iron containing waste materials such as fly ash and red mud [120].

The adsorption of arsenic by hydrous ferric oxide (FeOOH), particularly akaganeite, ferrihydrite, goethite and GFH, has been demonstrated to be very strong and effective [114]. The breakthrough behavior of a GFH fixed bed filter was investigated for arsenic removal and maximum uptakes of $28.9 \mathrm{mg} / \mathrm{g}$ and $42.7 \mathrm{mg} / \mathrm{g}$ at $\mathrm{pH} 7$ were achieved with initial low and high concentrations of $0-1 \mathrm{mg} / \mathrm{L}$ and $1-8 \mathrm{mg} / \mathrm{L}$, respectively [114]. The use of goethite for arsenic removal also achieved adsorption capacity of $25 \mathrm{mg} / \mathrm{g}$ [112]. The ability to use goethite to achieve a high arsenic removal rate was suggested in another study [134]. The achievement of higher arsenic uptakes of $65 \mathrm{mg} / \mathrm{g}$ at pH 3.5 and $22{ }^{\circ} \mathrm{C}$ [90] and of $120 \mathrm{mg} / \mathrm{g}$ at a $\mathrm{pH}$ range of $4.5-7$ and $25^{\circ} \mathrm{C}$ [111] has been successfully demonstrated with the use of a synthetic $\beta-\mathrm{FeOOH}$.

The iron oxyhydroxides used in these studies have particle sizes in the nanometer range. However, when used in sorption columns, nanoparticles can be problematic due to the difficulty in achieving solid/liquid separation [111]. It is therefore a major challenge to find a natural adsorbent that contains nanoparticles of iron oxides that can remove arsenic effectively and can also be used in column filtration technology.

The use of iron oxide coated sand (IOCS) as an adsorbent for removal of arsenic and iron has been investigated by UNESCO-IHE (The Netherlands) for 20 or more years. It is obtained as a by-product of the iron removal process within the Dutch groundwater treatment plants. The investigation of the use of IOCS obtained from different groundwater treatment plants in the Netherlands demonstrates that high to very high arsenic removal efficiencies were achieved for $\mathrm{As}(\mathrm{III})$ and $\mathrm{As}(\mathrm{V})$ depending on the iron and manganese content in their coatings. Arsenic removal efficiency of 100 percent was achieved with IOCS which contained $353.8 \mathrm{mg} \mathrm{Fe} / \mathrm{g}$ IOCS and $17.2 \mathrm{mg} \mathrm{Mn} / \mathrm{g}$ [135]. 


\subsubsection{Application of Nanoparticles for Arsenic Removal from Water}

Various nanomaterials have been employed for water treatment [136]. Their reactivities and high surface areas have attracted a lot of interest in their consideration as novel adsorbents for removal of heavy metals and arsenic [137]. Maiti et al. [138] have reviewed the use of nanomaterials for arsenic removal from water and some of the key nanomaterial technologies are summarized in this section. The implementation of these technologies has been limited by the costs of production and the difficulty in recovery and recycling of the nanoparticles. Of these, iron- and titanium-based nanoparticles are most commonly used for removal of arsenic [139-143].

The nano-adsorbents that have been considered for arsenic removal include nanoparticles of zero-valent iron (nZVI) [144,145], iron oxide nanoparticles $\alpha-\mathrm{Fe}_{2} \mathrm{O}_{3}, \mathrm{Fe}_{3} \mathrm{O}_{4}$ and $\alpha$ $\mathrm{FeOOH}[139,146,147]$. The arsenic removal capacity achieved with the iron oxide nanoparticles is influenced by the oxidation state of iron [143].

The oxidation of $\mathrm{As}(\mathrm{III})$ to $\mathrm{As}(\mathrm{V})$ is supported by the metal core and a thin layer of amorphous iron (oxy)hydroxide present in nanoparticles of nZVI [148]. Although nZVI is a useful adsorbent for arsenic removal, the production of toxic solid wastes from its synthesis is a main disadvantage [149].

Due to their high surface-to-volume ratios [75], iron oxide nanoparticles are 5-10 times more effective for arsenic removal than with the use of micron-sized particles [139]. Ultrafine hematite $\alpha-\mathrm{Fe}_{2} \mathrm{O}_{3}$ nanoparticles were successfully synthesized and used for treatment of laboratory-prepared and arsenic contaminated natural water [150]. Rapid removal of As(III) and $\mathrm{As}(\mathrm{V})$ was achieved, enabling removal of $74 \%$ of $\mathrm{As}(\mathrm{III})$ within $30 \mathrm{~min}$. The BET (Brunauer-Emmett-Teller) specific surface area was $162 \mathrm{~m}^{2} / \mathrm{g}$ and the average particle diameter was $5.0 \mathrm{~nm}$. The achieved adsorption capacity for As(III) was $95 \mathrm{mg} / \mathrm{g}$, while for $\mathrm{As}(\mathrm{V})$ it was much lower at $47 \mathrm{mg} / \mathrm{g}$.

The performance of magnetite nanoparticles which have a BET surface area of $69.4 \mathrm{~m}^{2} / \mathrm{g}$ and a mean particle diameter of $20 \mathrm{~nm}$ has also been investigated for arsenic removal [151] At $\mathrm{pH}>7$, the adsorption of $\mathrm{As}(\mathrm{V})$ rapidly decreases, while a more consistent adsorption was achieved for As(III) at $\mathrm{pH} 2-9$. The achieved adsorption capacity for As(III) was 8.0 $\mathrm{mg} / \mathrm{g}$ and was $8.8 \mathrm{mg} / \mathrm{g}$ for $\mathrm{As}(\mathrm{V})$. It was found that the presence of phosphate interfered with arsenic removal [151] and its removal prior to the treatment is recommended.

The removal of $\mathrm{As}(\mathrm{V})$ from water was investigated with a nanocomposite of silica and goethite [146]. The synthesized silica nanoparticles had particle sizes ranging from 150 to $250 \mathrm{~nm}$. The achieved adsorption capacity for the goethite/silica nanocomposite was $17.64 \mathrm{mg} / \mathrm{g}$ at $\mathrm{pH} 3.0$. The adsorption of $\mathrm{As}(\mathrm{V})$ on the nanocomposite was rapid, reaching equilibrium within $120 \mathrm{~min}$ [146].

Arsenic removal and photocatalytic oxidation of As(III) have been investigated in a number of studies with nanocrystalline titanium dioxide $\left(\mathrm{TiO}_{2}\right)$ [152-155]. The adsorption of $\mathrm{As}(\mathrm{III})$ and $\mathrm{As}(\mathrm{V})$ reached equilibrium on this nano-adsorbent within four hours and $80 \%$ or more of both species were adsorbed [152]. The photocatalytic efficiency of nanocrystalline $\mathrm{TiO}_{2}$ in oxidizing As(III) was also demonstrated, achieving full conversion in the presence of sunlight and dissolved oxygen to $\mathrm{As}(\mathrm{V})$ within $25 \mathrm{~min}$ [152].

Another titanium-based nano-adsorbent for $\mathrm{As}(\mathrm{III})$ which does not require oxidation to $\mathrm{As}(\mathrm{V})$ is hydrous titanium dioxide nanoparticles $\left(\mathrm{TiO}_{2} \times \mathrm{H}_{2} \mathrm{O}\right)$ [156]. High maximum adsorption capacities have been achieved with $\mathrm{TiO}_{2}$ nanoparticles for $\mathrm{As}(\mathrm{III})$. An adsorption capacity of $83 \mathrm{mg} / \mathrm{g}$ was achieved at a near neutral $\mathrm{pH}$, while at $\mathrm{pH} 9$ it was higher at $96 \mathrm{mg} / \mathrm{g}$ [157]. The titanium dioxide nanoparticles provided an effective, low-cost and single-step process for arsenic removal from contaminated water. Nevertheless, due to their particle sizes in the nanometer range, some care and extreme caution must be taken to prevent the possible dispersion of these nanoparticles into the environment [157]. This may be prevented or avoided by either granulation of these nanoparticles into micron-sized particles or loading onto very porous host materials [157].

The reported removal efficiencies achieved by some arsenic removal processes are summarized in Table 3. Evidently, the removal processes based on the use of $\mathrm{Fe}_{2} \mathrm{O}_{3}$ filter, 
As(III) oxidation by $(\mathrm{OCl}-)$ and Fe precipitation, enhanced coagulation/filtration with ferric chloride, iron doped activated carbon, hybrid activated alumina, iron based sorbents, layered double hydroxide (LDH), modified zeolites and laterite and limonite achieved removal efficiencies $\geq 95 \%$, thus demonstrating that processes involving oxidation and filtration, precipitation and adsorption are effective for removal of arsenic from contaminated water. The chosen process therefore depends on the simplicity and convenience of use if to be adopted for providing drinking water for human consumption.

Table 3. Treatment efficiencies reported for some arsenic removal processes.

\begin{tabular}{|c|c|c|}
\hline Treatment Process As(V) & Removal Efficiency & As Concentration \\
\hline \multicolumn{3}{|l|}{ Oxidation and Filtration } \\
\hline Aeration and filtration & $>90 \%$ & $300 \mu \mathrm{g} \mathrm{As}(\mathrm{III}) / \mathrm{L}$ \\
\hline $\mathrm{Fe}_{2} \mathrm{O}_{3}$ filter & $>95 \%$ & 100-400 $\mu \mathrm{g} \mathrm{As(III)/L}$ \\
\hline $\begin{array}{l}\text { As(III) oxidation by }(\mathrm{OCl}-) \\
\text { and Fe precipitation }\end{array}$ & $>98 \%$ & $300 \mu \mathrm{g} \mathrm{As}(\mathrm{III}) / \mathrm{L}$ \\
\hline \multicolumn{3}{|l|}{ Co-precipitation } \\
\hline Enhanced lime softening & $90 \%$ & \\
\hline $\begin{array}{c}\text { Enhanced } \\
\text { coagulation/filtration with } \\
\text { alum }\end{array}$ & $<90 \%$ & \\
\hline $\begin{array}{c}\text { Enhanced } \\
\text { coagulation/filtration with } \\
\text { ferric chloride }\end{array}$ & $95 \%$ & \\
\hline \multicolumn{3}{|l|}{ Adsorption } \\
\hline Iron doped activated carbon & $>95 \%$ & $311 \mu \mathrm{g} \mathrm{As} / \mathrm{L}$ \\
\hline Hybrid activated alumina & $>95 \%$ & $2-20 \mathrm{mg} \mathrm{As} / \mathrm{L}$ \\
\hline Iron based sorbents & Up to $98 \%$ & \\
\hline $\begin{array}{l}\text { Layered double hydroxide } \\
\text { (LDH) }\end{array}$ & Up to $96 \%$ & $300 \mu \mathrm{g} \mathrm{As}(\mathrm{V}) / \mathrm{L}$ \\
\hline Modified zeolites & Up to $99 \%$ & $100-400 \mu \mathrm{g}$ As $/ \mathrm{L}$ \\
\hline Modified clays & Up to $80 \%$ & $0.15 \mu \mathrm{M}$ As \\
\hline Laterite and limonite & Up to $95 \%$ & $500 \mu \mathrm{g} \mathrm{As} / \mathrm{L}$ \\
\hline
\end{tabular}

\section{Household Filter for Arsenic Removal for Drinking Water}

A major and impactful outcome from the various reported approaches for treatment of groundwater for removal of arsenic is their adoption in designing potable household filters that have been successfully used for treatment of groundwater as a source of domestic drinking water, particularly in under-developed countries. Several designs of arsenic filters have been developed, proposed and evaluated. Yet, there are still emerging new developments in this area.

One of the most successful domestic treatment units is the SONO filter which is a two-bucket system [158]. The composition of the upper bucket includes a composite iron layer ( $4-5 \mathrm{~cm}$ thick) of a mixture of metal iron and iron hydroxides. This layer is then covered with sand layers. Also, sand and charcoal layers are included in the lower bucket for removal of the iron hydroxides and residual organic matter. Figure 5 shows that the arsenic contaminated groundwater passes through coarse sand, composite iron matrix (CIM), brick chips and wood charcoal [158]. 


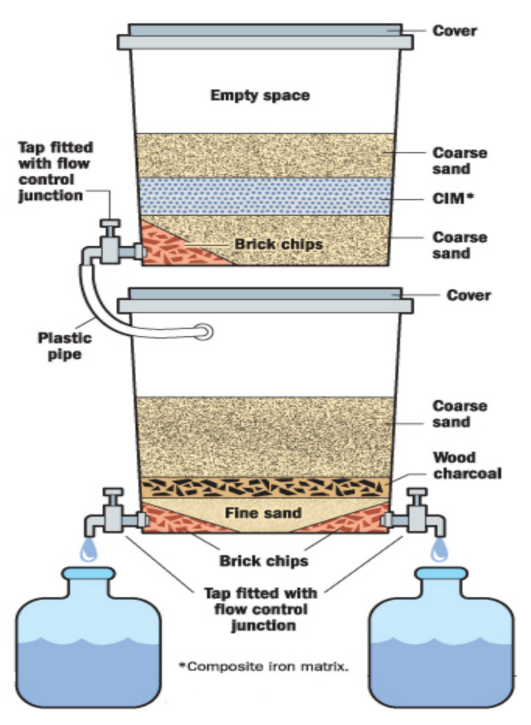

(a)

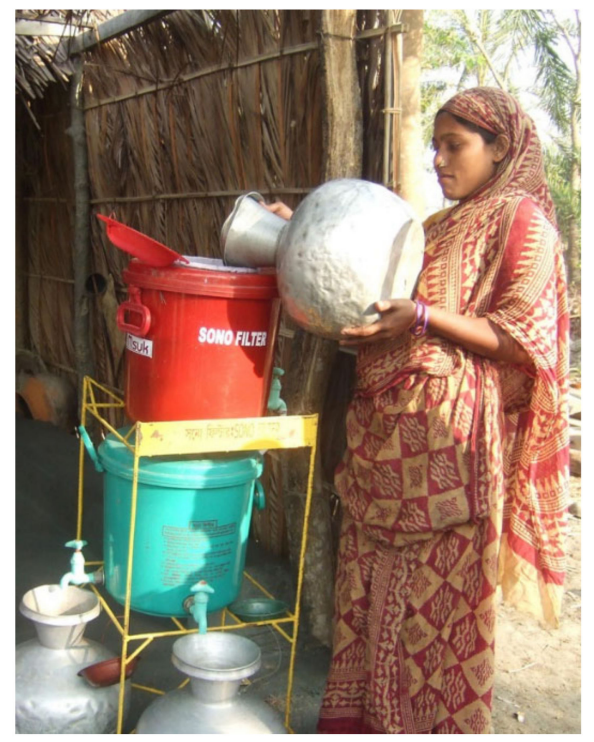

(b)

Figure 5. SONO Filter. (a) Schematic and (b) in domestic use [158]. Reproduced with permission from Taylor \& Francis.

The SONO filter which is manufactured in Bangladesh utilizes a composite iron matrix (CIM) to remove arsenic by complexation reactions on the metal surface as follows [158]:

$$
\begin{gathered}
\mathrm{FeOH}+\mathrm{H}_{2} \mathrm{AsO}_{4}{ }^{-} \rightarrow \mathrm{FeHAsO}_{4}{ }^{-}+\mathrm{H}_{2} \mathrm{O} \text { and } \\
\mathrm{FeOH}+\mathrm{HAsO}_{4}{ }^{2-} \rightarrow \mathrm{FeAsO}_{4}{ }^{2-}+\mathrm{H}_{2} \mathrm{O}
\end{gathered}
$$

These reactions occur without the need for any pre- or post-chemical treatment. Also no regeneration is required and no toxic wastes are produced [158]. The resulting spent material from the arsenic removal process is a solid self-contained iron-arsenate cement which is non-toxic and does not leach out when in contact with rainwater.

The arsenic concentrations in contaminated groundwater used in one study ranged from 5-4000 $\mu \mathrm{g} / \mathrm{L}$, but these were reduced to 3-30 $\mu \mathrm{g} / \mathrm{L}$ after treatment [158]. The treated waters from the filter were found to meet the limits of $10 \mu \mathrm{g} / \mathrm{L}$ and $50 \mu \mathrm{g} / \mathrm{L}$ set by $\mathrm{WHO}$ and the Bangladeshi government, respectively. Also, the filter is relatively cheap costing about $\$ 40$ for over five years operation and capable of producing 20-30 L/hour to support one to two families drinking and cooking needs [158]. The approval for use of the filter was granted by government and at the early stages about 30,000 of these filters were provided throughout Bangladesh. Its use subsequently spread to India, Nepal and Pakistan. The National Academy of Engineering has recognized the innovation of the SONO filter for arsenic removal by awarding it the Grainger Challenge Prize for sustainability due to "its affordability, reliability, ease of maintenance, social acceptability, and environmental friendliness [158]".

With regards to ongoing maintenance of SONO filters, an important requirement is the need to flush each bucket with $5 \mathrm{~L}$ of hot water to eliminate pathogenic bacteria and minimize coliform counts. The filter is expected to last for five years, but if the flow rate decreases, it can be improved by removing the sand layers for washing and reuse or replacement with new sand.

Another commonly used arsenic filter for treatment of contaminated water for arsenic removal is the Kanchan ${ }^{\mathrm{TM}}$ Arsenic Filter (KAF) [159]. This filter was developed in 2003 through a collaborative effort between the Massachusetts Institute of Technology (MIT) and Environment and Public Health Organization on the mitigation of arsenic contamination of groundwater [160]. 
Figure 6 shows that the components of a KAF include a plastic container, PVC pipe, diffuser basin, brick chips, iron nails, fine sand, coarse sand and gravel [160]. The arsenic contaminated groundwater is poured into the diffuser basin where it comes into contact with the brick particles and iron nails. Upon contact with water and air, the iron nails rust, consequently producing ferric hydroxide particles that quickly adsorb arsenic from the water. The adsorption process is repeated when new iron surfaces are exposed as the outer surfaces scale off. These continuous processes result in the retention of arsenic on the filter components and produce drinkable filtered water. In addition, the KAF is capable of removing pathogens from the water.

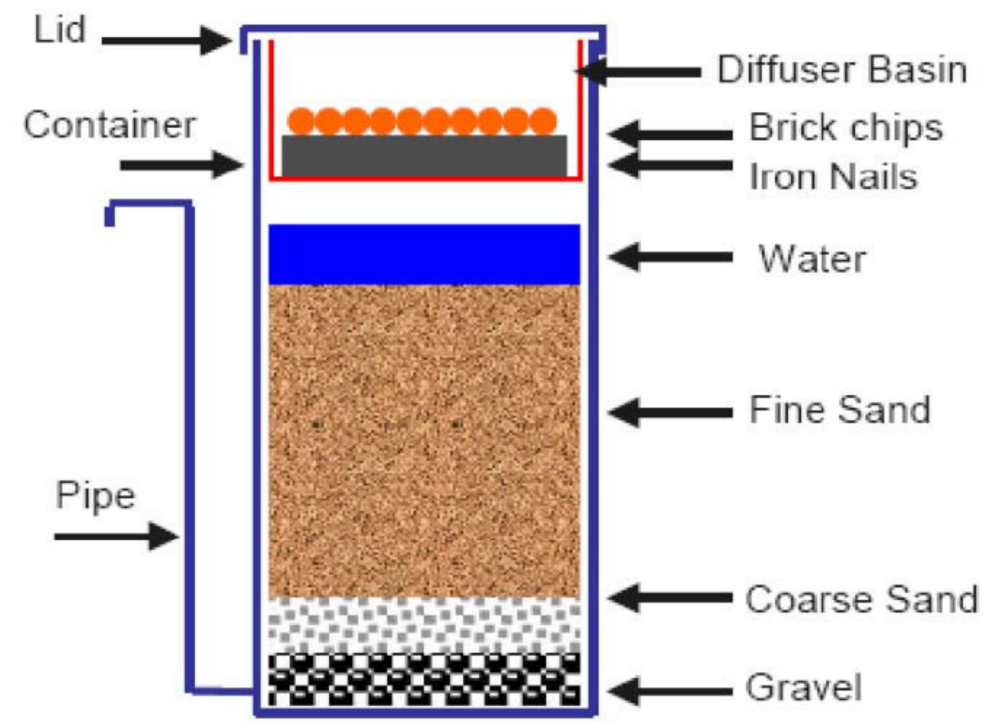

Figure 6. Components of a Kanchan Arsenic Filter [160]. Reproduced with permission from Taylor \& Francis.

Factors influencing the performance of a KAF include arsenic concentration, duration of use, filter maintenance, flow rate, monitoring and handling and other water components (such as water hardness, iron, chloride and phosphate concentrations) [161]. The effectiveness of KAFs in reducing the concentration of arsenic in groundwater to less than $50 \mu \mathrm{g} / \mathrm{L}$ has been demonstrated [160]. But the effectiveness of the filter can be affected occasionally by the unexpected and unpredictable variability of groundwater conditions, arsenic concentration and climatic conditions.

One of the more recently developed filters is the Pakistan Arsenic Filter (PAF) [162]. This unit employs three different forms of iron (mesh, nails and slag). The iron is held down in a plastic bucket $(25 \mathrm{~L}$ ) with diffuser plates. A tap is attached to the bucket to enable the adjustment of water level and for taking samples at the completion of the treatment, as shown in Figure 7. 


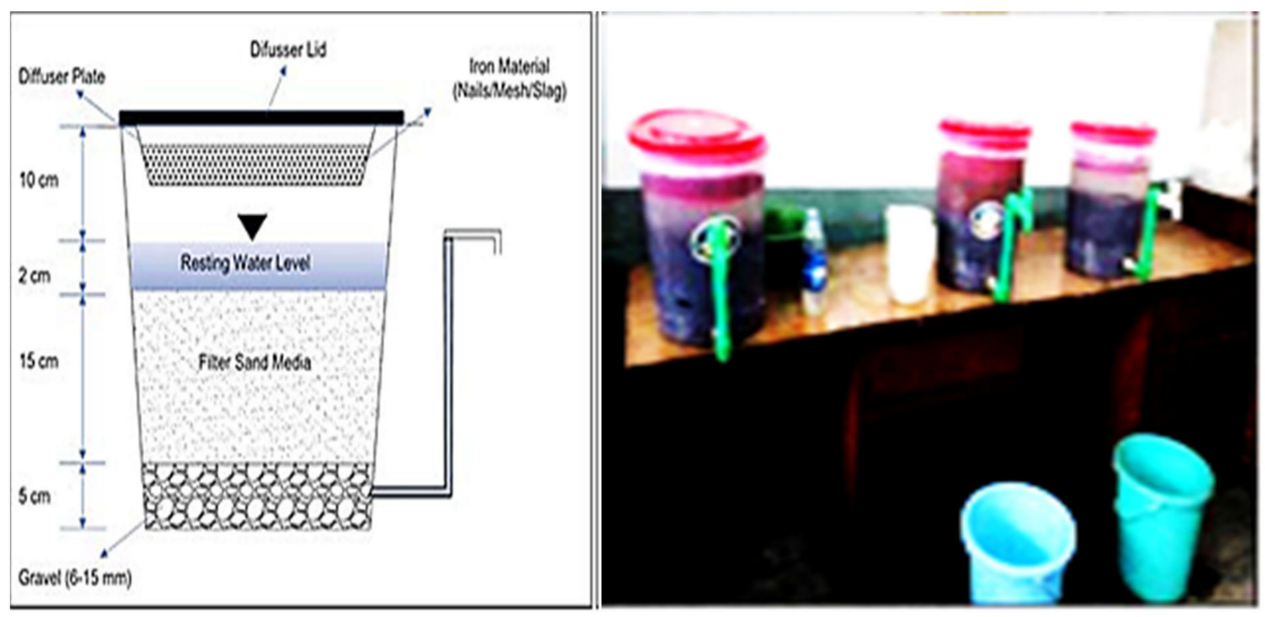

Figure 7. Components of a Pakistan Arsenic Filter (PAF) and its use for arsenic removal from groundwater [162]. Reproduced with permission.

Figure 7 shows the specific components of a PAF. The round gravel layer overlaid by sand layer can be seen at the bottom. The unit used $1 \mathrm{~kg}$ of iron (mesh, nails and slag) contained within the diffuser plate in the bucket and the rate of water flow through the filter is $30 \mathrm{~L} / \mathrm{min}$ which decreased over an 8-week trial period to $20 \mathrm{~L} / \mathrm{min}$ [162]. The arsenic contaminated groundwater goes through a diffuser plate and then passes through the sand and gravel. Treated water is transferred through a plastic pipe via a tap, as shown in Figure 7. The highest efficiency achieved for arsenic removal was with the use of iron mesh due to its larger surface area which generates more ferric hydroxide. The PAF was produced at a cost of US\$ 5 which is affordable and accessible to more people [162]. However, it is only applicable to contaminated water which contains 50 to $100 \mu \mathrm{g} / \mathrm{L}$ arsenic, but it was suggested that the unit can be used in series to achieve improved arsenic removal.

Besides the few examples of arsenic filters highlighted in this paper, there are many other filters used or proposed for removal of arsenic from groundwater for domestic consumption. We have decided to describe only the selected few that have had significant impact for domestic provision of suitable drinking water. Also, it is important to note that there is ongoing research to develop simpler and easier to use filter systems.

\section{Conclusions and Future Considerations}

This review has demonstrated that arsenic contamination of groundwater impacts the availability of safe and good quality water for domestic use (drinking and cooking) and agriculture in under-developed countries such as Bangladesh, India, Pakistan and Nepal, as well as some parts of more developed countries such as the USA. This can have dire consequences on human health, agriculture, economic and social well-being. The need for a good understanding of the chemistry of arsenic and its fate in the environment has also been demonstrated to be very important for dealing with or minimising the consequences of groundwater contamination by arsenic. The case study about Bangladesh provided a sharp focus on the dire consequences and impact of groundwater contamination by arsenic with serious health, agricultural, social and economic impacts. Furthermore, it highlights that when groundwater contamination by arsenic is identified, rapid efforts need to be directed to reducing/minimizing the associated impacts by adopting and utilising relevant treatment and removal strategies, as well as seeking alternatives for drinking water sources where possible. Socio-economic factors will also play a significant role in the adoption of safer drinking water options. A recent study in Bangladesh illustrated the need for public education combined with the provision of alternative drinking water sources to overcome attitudes and the reluctance of people to switch to better alternatives [163]. The adoption of many of these strategies in the development of various filter systems for arsenic removal 
has had a great impact on the ability of people to access safe drinking water in some parts of the affected countries and communities. Many of the available potable treatment systems are effective in ensuring the removal and minimisation of arsenic in groundwater dependent communities to acceptable local standards. However, there are still issues with the long-term maintenance of these systems, especially in ensuring ongoing effective removal of arsenic, disinfection, filter replacement and sludge disposal. Ongoing education of local communities on how to maintain these systems, including how often the filters should be replaced and disinfection protocols is necessary to ensure safety, particularly where there is no alternative water source to groundwater. There is therefore still a need for ongoing research on developing more robust and highly effective filter systems for arsenic removal from groundwater for use for domestic consumption, with the aim of further reducing capital and operation costs, improving user friendliness, minimizing maintenance requirements and resolving or eliminating the need for sludge management and disposal. Also, portable devices that can be adopted for household and community monitoring of arsenic concentrations in drinking water are now available [164,165]. Das et al. [164] have developed two low-cost field test kits for detection of arsenic in water. These kits are capable of detecting as low as $10 \mu \mathrm{g} / \mathrm{L}$ of total arsenic in groundwater within $7 \mathrm{~min}$. In addition, there are commercially available quick test systems for arsenic detection in water within $12 \mathrm{~min}$ [165]. If adopted, these devices will ensure communities can adequately assess their water safety and, thus, minimize the incidences of arsenic poisoning. Furthermore, the use of various nanomaterials will play a significant role in the development of a next generation efficient filter system. In the long-term, the development of a more affordable version of the ArsenicMaster Whole House Arsenic Water Filtration System [166], shown in Figure 8, which is maintenance-free will go a long way to addressing the various issues with existing filters if it can be designed to suit the arsenic levels found in groundwater in the under-developed countries and remote communities at a reasonable capital cost.

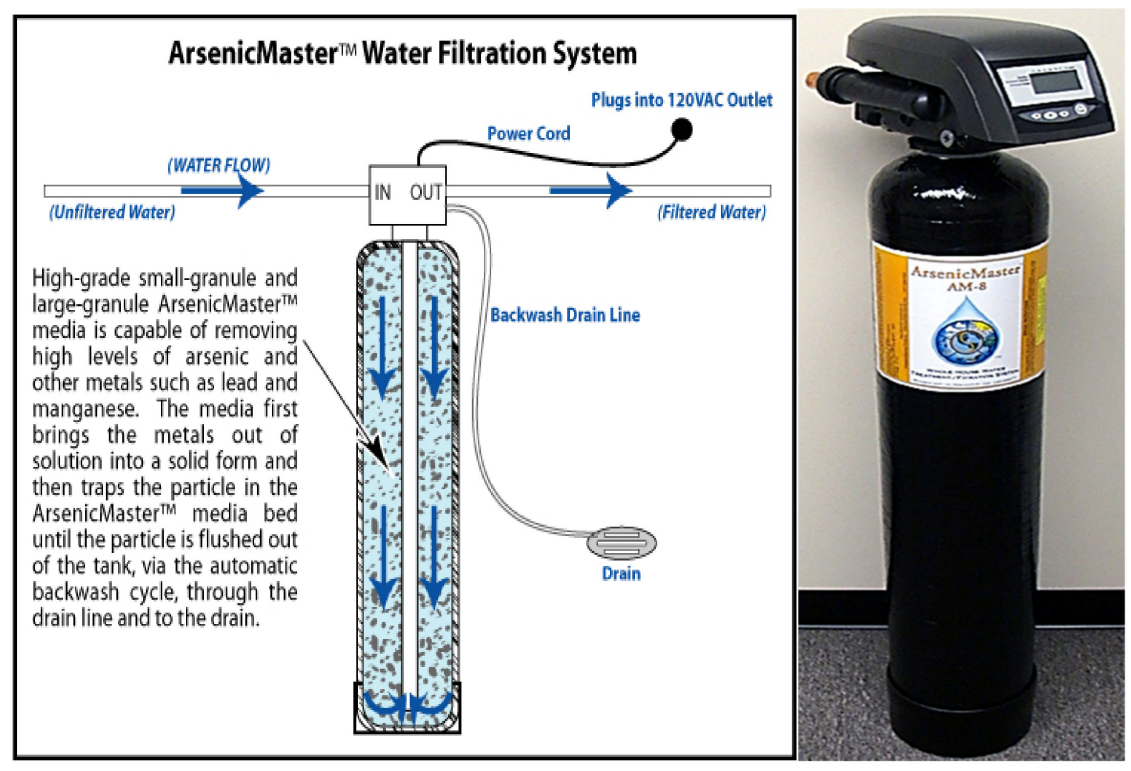

Figure 8. Components of the ArsenicMaster Whole House Arsenic Water Filtration System and a commercially available version [166]. Reproduced with permission.

Author Contributions: Conceptualization, S.B.A. and S.K.; methodology, S.B.A., S.K. and A.F.P.; formal analysis, S.B.A., S.K. and A.F.P.; investigation, S.B.A. and S.K.; resources, S.B.A. and A.F.P.; data curation, S.K and S.B.A.; Writing-Original draft preparation, S.K., S.B.A. and A.F.P.; WritingReview and editing, S.K., S.B.A. and A.F.P.; visualization, S.B.A.; supervision, S.B.A. and A.F.P.; project administration, S.B.A.; funding acquisition, S.B.A. All authors have read and agreed to the published version of the manuscript. 
Funding: This research received no external funding.

Institutional Review Board Statement: Not applicable.

Informed Consent Statement: Not applicable.

Data Availability Statement: Not applicable for a review paper.

Acknowledgments: The provision of postgraduate research scholarships and research facilities by Monash University to S.K. is gratefully acknowledged.

Conflicts of Interest: The authors declare no conflict of interest and that the funders had no role in the design of the study; in the collection, analyses, or interpretation of data; in the writing of the manuscript, or in the decision to publish the results.

\section{References}

1. Mandal, B.K.; Suzuki, K.T. Arsenic round the world: A review. Talanta 2002, 58, 201-235. [CrossRef]

2. Singh, R.; Singh, S.; Parihar, P.; Singh, V.P.; Prasad, S.M. Arsenic contamination, consequences and remediation techniques: A review. Ecotoxicol. Environ. Saf. 2015, 112, 247-270. [CrossRef] [PubMed]

3. Shankar, S.; Shanker, U.; Shikha. Arsenic contamination of groundwater: A review of sources, prevalence, health risks, and strategies for mitigation. Sci. World J. 2014, 2014, 1-18. [CrossRef] [PubMed]

4. Shaji, E.; Santosh, M.; Sarath, K.; Prakash, P.; Deepchand, V.; Divya, B. Arsenic contamination of groundwater: A global synopsis with focus on the Indian Peninsula. Geosci. Front. 2021, 12, 101079. [CrossRef]

5. Ali, W.; Rasool, A.; Junaid, M.; Zhang, H. A comprehensive review on current status, mechanism, and possible sources of arsenic contamination in groundwater: A global perspective with prominence of Pakistan scenario. Environ. Geochem. Health 2019, 41, 737-760. [CrossRef]

6. Saha, N.; Rahman, M.S. Groundwater hydrogeochemistry and probabilistic health risk assessment through exposure to arseniccontaminated groundwater of Meghna floodplain, central-east Bangladesh. Ecotoxicol. Environ. Saf. 2020, 206, 111349. [CrossRef]

7. Mohan, D.; Pittman, C.U., Jr. Arsenic removal from water/wastewater using adsorbents-A critical review. J. Hazard. Mater. 2007, 142, 1-53. [CrossRef]

8. Ahmed, M.F.; Ali, M.A. Environmental Chemistry of Arsenic, Arsenic Contamination: Bangladesh Perspective; International Training Network BUET: Dhaka, Bangladesh, 2003; pp. 21-41.

9. Smedley, P.; Kinniburgh, D. A review of the source, behaviour and distribution of arsenic in natural waters. Appl. Geochem. 2002, 17, 517-568. [CrossRef]

10. Azcue, J.M.; Nriagu, J.O. Arsenic historical perspective. In Arsenic in the Environment; Part, J., Nriagu, J.O., Eds.; John Wiley \& Sons: London, UK, 1994; pp. 1-49.

11. Sharma, V.K.; Sohn, M. Aquatic arsenic: Toxicity, speciation, transformations, and remediation. Environ. Int. 2009, 35, 743-759. [CrossRef]

12. Gupta, D.K.; Srivastava, S.; Huang, H.; Romero-Puertas, M.C.; Sandalio, L.M. Detoxification of Heavy Metals; Springer: Cham, Switzerland, 2011; pp. 169-179.

13. Al-Abed, S.R.; Jegadeesan, G.; Purandare, J.; Allen, D. Arsenic release from iron rich mineral processing waste: Influence of pH and redox potential. Chemosphere 2007, 66, 775-782. [CrossRef] [PubMed]

14. Bodek, I. Environmental Inorganic Chemistry: Properties, Processes, and Estimation Methods; Pergamon Press: New York, NY, USA, 1988.

15. Singh, M.K.; Kumar, A. A global problem of arsenic in drinking water and its mitigation-A review. Int. J. Adv. Eng. Technol. 2012, 3, 196-203.

16. Cassone, G.; Chillé, D.; Foti, C.; Giuffrè, O.; Ponterio, R.; Sponer, J.; Saija, F. Stability of hydrolytic arsenic species in aqueous solutions: As3+ vs. As5+. Phys. Chem. Chem. Phys. 2018, 20, 23272-23280. [CrossRef]

17. Quinodóz, F.B.; Maldonado, L.; Blarasin, M.; Matteoda, E.; Lutri, V.; Cabrera, A.; Albo, J.G.; Giacobone, D. The development of a conceptual model for arsenic mobilization in a fluvio-eolian aquifer using geochemical and statistical methods. Environ. Earth Sci. 2019, 78, 206. [CrossRef]

18. Syafiuddin, A.; Boopathy, R.; Hadibarata, T. Challenges and solutions for sustainable groundwater usage: Pollution control and integrated management. Curr. Pollut. Rep. 2020, 6, 310-327. [CrossRef]

19. Csalagovits, I. Arsenic-bearing artesian waters of Hungary. Annu. Rep. Geol. Inst. Hung. 1999, 1992-1993/II, 85-92.

20. Rowland, H.A.; Omoregie, E.O.; Millot, R.; Jimenez, C.; Mertens, J.; Baciu, C.; Hug, S.J.; Berg, M. Geochemistry and arsenic behaviour in groundwater resources of the Pannonian Basin (Hungary and Romania). Appl. Geochem. 2011, 26, 1-17. [CrossRef]

21. Bundschuh, J.; Armienta, M.A.; Birkle, P. Natural Arsenic in Groundwaters of Latin America; CRC Press: New York, NY, USA, 2008.

22. UNICEF. Arsenic Mitigation in Bangladesh Fact Sheet. 2010. Available online: http://www.unicef.org/bangladesh/Arsenic.pdf (accessed on 12 December 2020).

23. WHO. Guidelines for Drinking-Water Quality: Recommendations, 3rd ed.; World Health Organization: Geneva, Switzerland, 2004; Volume 1. 
24. BGS; DPHE. Arsenic Contamination of Groundwater in Bangladesh; Final, Report; British Geological Survey: Keyworth, UK; Department of Public Health Engineering: Dhaka, Bangladesh, 2001; Volume 2.

25. Herath, I.; Vithanage, M.; Bundschuh, J.; Maity, J.P.; Bhattacharya, P. Natural arsenic in global groundwaters: Distribution and geochemical triggers for mobilization. Curr. Pollut. Rep. 2016, 2, 68-89. [CrossRef]

26. BBS. Per Capaita Income of Bangladesh: Bangladesh Bureau of Staticts; Ministry of Planning, Government of Bangladesh: Dhaka, Bangladesh, 2016.

27. BGS. Groundwater Studies for Arsenic Contamination in Bangladesh; Main report and, supplemental; Government of the Peoples Republic of Bangladesh: Dhaka, Bangladesh; Ministry of Local Government, Rural Development and Cooperatives: Dhaka, Bangladesh; Department of Public Health Engineering: Dhaka, Bangladesh; Mott MacDonald International Ltd.: London, UK, 2000; Volume 1-3.

28. GoB; UNDP. Millennium Development Goals Needs Assessment E Costing 2009-2015 Bangladesh; Government of Bangladesh: Dhaka, Bangladesh; UNDP: New York, NY, USA, 2015.

29. Tan, S.N.; Yong, J.W.H.; Ng, Y.F. Arsenic exposure from drinking water and mortality in Bangladesh. Lancet 2010, 376, 1641-1642. [CrossRef]

30. Ahmed, M.F.; Ahmed, T. Status of remediation of arsenic contamination of groundwater in Bangladesh. Compr. Water Qual. Purif. 2014, 1, 104-121.

31. Polizzotto, M.L.; Harvey, C.F.; Li, G.; Badruzzman, B.; Ali, A.; Newville, M.; Sutton, S.; Fendorf, S. Solid-phases and desorption processes of arsenic within Bangladesh sediments. Chem. Geol. 2006, 228, 97-111. [CrossRef]

32. Uddin, A.; Shamsudduha, M.; Saunders, J.; Lee, M.-K.; Ahmed, K.M.; Chowdhury, M. Mineralogical profiling of alluvial sediments from arsenic-affected Ganges-Brahmaputra floodplain in central Bangladesh. Appl. Geochem. 2011, 26, 470-483. [CrossRef]

33. Harvey, C.F.; Ashfaque, K.N.; Yu, W.; Badruzzaman, A.; Ali, M.A.; Oates, P.M.; Michael, H.A.; Neumann, R.B.; Beckie, R.; Islam, S.; et al. Groundwater dynamics and arsenic contamination in Bangladesh. Chem. Geol. 2006, 228, 112-136. [CrossRef]

34. McArthur, J.M.; Banerjee, D.M.; Hudson-Edwards, K.A.; Mishra, R.; Purohit, R.; Ravenscroft, P.; Cronin, A.; Howarth, R.J.; Chatterjee, A.; Talukder, T.; et al. Natural organic matter in sedimentary basins and its relation to arsenic in anoxic ground water: The example of West Bengal and its worldwide implications. Appl. Geochem. 2004, 19, 1255-1293. [CrossRef]

35. Bundschuh, J.; Bhattacharya, P.; Sracek, O.; Mellano, M.F.; Ramírez, A.E.; Storniolo, A.D.R.; Martín, R.A.; Cortés, J.; Litter, M.I.; Jean, J.-S. Arsenic removal from groundwater of the Chaco-Pampean Plain (Argentina) using natural geological materials as adsorbents. J. Environ. Sci. Heal. Part A 2011, 46, 1297-1310. [CrossRef]

36. Acharyya, S.K.; Shah, B.A. Groundwater arsenic pollution affecting deltaic West Bengal, India. Curr. Sci. 2010, 99, 1787-1794.

37. Mallick, S.; Rajagopal, N. Groundwater development in the arsenic-affected alluvial belt of West Bengal—Some questions. Curr. Sci. 1996, 70, 956-958.

38. Mandal, B.K.; Chowdhury, T.R.; Samanta, G.; Mukherjee, D.P.; Chanda, C.R.; Saha, K.C.; Chakraborti, D. Impact of safe water for drinking and cooking on five arsenic-affected families for 2 years in West Bengal, India. Sci. Total. Environ. 1998, 218, 185-201. [CrossRef]

39. Singh, A.K. Chemistry of arsenic in groundwater of Ganges-Brahmaputra river basin. Curr. Sci. 2006, 91, 599-606.

40. Fazal, M.A.; Kawachi, T.; Ichion, E. Extent and severity of groundwater arsenic contamination in Bangladesh. Water Int. 2001, 26, 370-379. [CrossRef]

41. Acharyya, S. Arsenic in Groundwater-Geological Overview: Consultation on Arsenic in Drinking Water; World Health Organization (WHO): New Delhi, India, 1997.

42. Safiuddin, M.; Shirazi, S.M.; Yussof, S. Arsenic contamination of groundwater in Bangladesh: A review. Int. J. Phys. Sci. 2011, 6, 6791-6800. [CrossRef]

43. Nickson, R.; McArthur, J.; Burgess, W.; Ahmed, K.M.; Ravenscroft, P.; Rahmanñ, M. Arsenic poisoning of Bangladesh groundwater. Nat. Cell Biol. 1998, 395, 338. [CrossRef]

44. Fendorf, S.; Michael, H.A.; Van Geen, A. Spatial and temporal variations of groundwater arsenic in south and southeast Asia. Science 2010, 328, 1123-1127. [CrossRef]

45. Reza, A.S.; Jean, J.-S.; Yang, H.-J.; Lee, M.-K.; Woodall, B.; Liu, C.-C.; Lee, J.-F.; Luo, S.-D. Occurrence of arsenic in core sediments and groundwater in the Chapai-Nawabganj District, northwestern Bangladesh. Water Res. 2010, 44, 2021-2037. [CrossRef] [PubMed]

46. McArthur, J.M.; Ravenscroft, P.; Safiulla, S.; Thirlwall, M.F. Arsenic in groundwater: Testing pollution mechanisms for sedimentary aquifers in Bangladesh. Water Resour. Res. 2001, 37, 109-117. [CrossRef]

47. Maity, J.P.; Nath, B.; Kar, S.; Chen, C.-Y.; Banerjee, S.; Jean, J.-S.; Liu, M.-Y.; Centeno, J.A.; Bhattacharya, P.; Chang, C.L.; et al. Arsenic-induced health crisis in peri-urban Moyna and Ardebok villages, West Bengal, India: An exposure assessment study. Environ. Geochem. Health 2012, 34, 563-574. [CrossRef] [PubMed]

48. Islam, M.; Islam, F. Arsenic Contamination in Groundwater in Bangladesh: An Environmental and Social Disaster; IWA Water Wiki: London, UK, 2010; Available online: www.iwawaterwiki.org (accessed on 16 December 2020).

49. Safiuddin, M.; Karim, M. Groundwater arsenic contamination in Bangladesh: Causes, effects and remediation. In Proceedings of the 1st International Conference and Annual Paper Meet on Civil Engineering, Chittagong, Bangladesh, 2-3 November 2016; Volume 43, pp. 79-84. 
50. Huq, S.I.; Joardar, J.; Parvin, S.; Correll, R.; Naidu, R. Arsenic contamination in food-chain: Transfer of arsenic into food materials through groundwater irrigation. J. Heal. Popul. Nutr. 2006, 24, 305-316.

51. Khan, S.I.; Ahmed, A.M.; Yunus, M.; Rahman, M.; Hore, S.K.; Vahter, M.; Wahed, M. Arsenic and cadmium in food-chain in Bangladesh-An exploratory study. J. Heal. Popul. Nutr. 2010, 28, 578-584. [CrossRef]

52. ITNC Position Paper on Bangladesh Response to Arsenic Contamination of Groundwater; International Training Network Centre, Bangladesh University of Engineering and Technology (BUET): Dhaka, Bangladesh, 2008.

53. SOES; DCH. Groundwater Arsenic Contamination in Bangladesh; A summarized survey, report; The School of Environmental Studies, Jadavpur University: Kolkata, India; Dhaka Community Hospital: Dhaka, Bangladesh, 2000.

54. Dhar, R.K.; Biswas, B.K.; Samanta, G.; Mandal, B.K.; Chakraborti, D.; Roy, S.; Jafar, A.; Islam, A.; Ara, G.; Kabir, S.; et al. Groundwater arsenic calamity in Bangladesh. Curr. Sci. 1997, 73, 48-59.

55. Farmer, J.G.; Johnson, L.R. Assessment of occupational exposure to inorganic arsenic based on urinary concentrations and speciation of arsenic. Occup. Environ. Med. 1990, 47, 342-348. [CrossRef]

56. Arnold, H.; Odam, R.; James, W. Diseases of the Skin: Clinical Dermatology, 8th ed.; WB Sanders: Philadelphia, PA, USA, 1990.

57. Tchounwou, P.B.; Yedjou, C.G.; Udensi, U.K.; Pacurari, M.; Stevens, J.J.; Patlolla, A.K.; Noubissi, F.; Kumar, S. State of the science review of the health effects of inorganic arsenic: Perspectives for future research. Environ. Toxicol. 2019, 34, 188-202. [CrossRef]

58. WHO. Guidelines for Drinking Water Quality; WHO: Geneva, Switzerland, 2011; Volume 4, pp. 315-318.

59. Dastgiri, S.; Mosaferi, M.; Fizi, M.A.; Olfati, N.; Zolali, S.; Pouladi, N.; Azarfam, P. Arsenic exposure, dermatological lesions, hypertension, and chromosomal abnormalities among people in a rural community of northwest Iran. J. Health Popul. Nutr. 2010, 28, 14-22. [PubMed]

60. Lazaroff, C. Arsenic Standard Delayed by Call for More Studies; Environment News Service: 2001. Available online: www.ensnewswire.com (accessed on 10 October 2011).

61. Smith, A. Report and Action Plan for Arsenic in Drinking Water Focusing on Health, Bangladesh; Assignment Report (WHO Project BAN CWS 001); World Health Organization (WHO): New Delhi, India, 1997; p. 9.

62. Yunus, M.; Sohel, N.; Hore, S.K.; Rahman, M. Arsenic exposure and adverse health effects: A review of recent findings from arsenic and health studies in Matlab, Bangladesh. Kaohsiung J. Med Sci. 2011, 27, 371-376. [CrossRef] [PubMed]

63. Khalequzzaman, M.; Faruque, F.S.; Mitra, A.K. Assessment of Arsenic Contamination of Groundwater and Health Problems in Bangladesh. Int. J. Environ. Res. Public Health 2005, 2, 204-213. [CrossRef]

64. Karim, M.M. Arsenic in groundwater and health problems in Bangladesh. Water Res. 2000, 34, 304-310. [CrossRef]

65. Asadullah, M.N.; Chaudhury, N. Poisoning the mind: Arsenic contamination of drinking water wells and children's educational achievement in rural Bangladesh. Econ. Educ. Rev. 2011, 30, 873-888. [CrossRef]

66. Sohel, N.; Vahter, M.; Ali, M.; Rahman, M.; Rahman, A.; Streatfield, P.K.; Kanaroglou, P.S.; Persson, L. Åke spatial patterns of fetal loss and infant death in an arsenic-affected area in Bangladesh. Int. J. Heal. Geogr. 2010, 9, 53. [CrossRef]

67. Bhattacharya, P.; Samal, A.C.; Majumdar, J.; Santra, S.C. Arsenic contamination in rice, wheat, pulses, and vegetables: A study in an arsenic affected area of West Bengal, India. Water Air Soil Pollut. 2010, 213, 3-13. [CrossRef]

68. Martin, M.; Ferdousi, R.; Hossain, K.M.J.; Barberis, E. Arsenic from groundwater to paddy fields in Bangladesh: Solid-liquid partition, sorption and mobility. Water Air and Soil Pollut. 2010, 212, 27-36. [CrossRef]

69. Rahman, M.A.; Hasegawa, H. High levels of inorganic arsenic in rice in areas where arsenic-contaminated water is used for irrigation and cooking. Sci. Total Environ. 2011, 409, 4645-4655. [CrossRef]

70. Saha, N.; Zaman, M.R. Concentration of selected toxic metals in groundwater and some cereals grown in Shibganj area of Chapai Nawabganj, Rajshahi, Bangladesh. Curr. Sci. 2011, 101, 427-431.

71. Williams, P.; Islam, M.; Hussain, S.; Meharg, A. Arsenic absorption by rice. Behavior of Arsenic in Aquifers, Soils and Plants. (Conference Proceedings), Dhaka, Bangladesh, 16-18th January 2005.

72. Kumarathilaka, P.; Seneweera, S.; Ok, Y.S.; Meharg, A.A.; Bundschuh, J. Mitigation of arsenic accumulation in rice: An agronomical, physicochemical, and biological approach-A critical review. Crit. Rev. Environ. Sci. Technol. 2020, 50, 31-71. [CrossRef]

73. Jiang, J.-Q.; Ashekuzzaman, S.M.; Jiang, A.; Sharifuzzaman, S.M.; Chowdhury, S.R. Arsenic contaminated groundwater and its treatment options in Bangladesh. Int. J. Environ. Res. Public Health 2013, 10, 18-46. [CrossRef] [PubMed]

74. Ahmed, A.A.M.; Alam, J.B.; Ahmed, A.A.M. Evaluation of socioeconomic impact of arsenic contamination in Bangladesh. J. Toxicol. Environ. Health Sci. 2011, 3, 298-307.

75. Mahmood, S.; Halder, A. The socioeconomic impact of arsenic poisoning in Bangladesh. J. Toxicol. Environ. Health Sci. 2011, 3, 65-73.

76. Ahmad, S.A.; Sayed, M.H.; Khan, M.H.; Karim, M.N.; Haque, M.A.; Bhuiyan, M.S. Sociocultural aspects of arsenicArsenicosis in Bangladesh: Community perspective. J. Environ. Sci. Health A Toxicol. Hazard Subst Environ. Eng. 2007, 42, 1945-1958. [CrossRef]

77. Rahmana, M.A.; Rahmanc, A.; Kaiser Khan, M.Z.; Renzahod, A.M.N. Human health risks and socio-economic perspectives of arsenic exposure in Bangladesh: A scoping review. Ecotoxicol. Environ. Saf. 2018, 150, 335-343. [CrossRef]

78. Guha Mazumder, D.; Dasgupta, U.B. Chronic arsenic toxicity: Studies in West Bengal, India. Kaohsiung J. Med. Sci. 2011, 27, 360-370. [CrossRef] [PubMed]

79. Alka, S.; Shahir, S.; Ibrahim, N.; Ndejiko, M.J.; Vo, D.-V.N.; Manan, F.A. Arsenic removal technologies and future trends: A mini review. J. Clean. Prod. 2021, 278, 123805. [CrossRef] 
80. Weerasundara, L.; Ok, Y.-S.; Bundschuh, J. Selective removal of arsenic in water: A critical review. Environ. Pollut. 2021, 268, 115668. [CrossRef] [PubMed]

81. Jain, C.K.; Singh, R.D. Technological options for the removal of arsenic with special reference to South East Asia. J. Environ. Manag. 2012, 107, 1-18. [CrossRef]

82. Ghurye, G.; Clifford, D.; Tripp, A. Iron coagulation and direct microfiltration to remove arsenic from groundwater. J. Am. Water Work. Assoc. 2004, 96, 143-152. [CrossRef]

83. Leupin, O.X.; Hug, S.J. Oxidation and removal of arsenic (III) from aerated groundwater by filtration through sand and zero-valent iron. Water Res. 2005, 39, 1729-1740. [CrossRef]

84. Bissen, M.; Frimmel, F.H. Arsenic-A review. Part II: Oxidation of arsenic and its removal in water treatment. Acta Hydrochim. Hydrobiol. 2003, 31, 97-107. [CrossRef]

85. Katsoyiannis, I.A.; Zouboulis, A.I. Application of biological processes for the removal of arsenic from groundwaters. Water Res. 2004, 38, 17-26. [CrossRef]

86. Pokhrel, D.; Viraraghavan, T. Arsenic removal from an aqueous solution by a modified fungal biomass. Water Res. 2006, 40, 549-552. [CrossRef]

87. Hering, J.G.; Chen, P.-Y.; Wilkie, J.A.; Elimelech, M. Arsenic removal from drinking water during coagulation. J. Environ. Eng. 1997, 123, 800-807. [CrossRef]

88. Chen, H.-W.; Frey, M.M.; Clifford, D.; McNeill, L.S.; Edwards, M. Arsenic treatment considerations. J. Am. Water Work. Assoc. 1999, 91, 74-85. [CrossRef]

89. Lakshmipathiraj, P.; Narasimhan, B.R.V.; Prabhakar, S.; Raju, G.B. Adsorption of arsenate on synthetic goethite from aqueous solutions. J. Hazard. Mater. 2006, 136, 281-287. [CrossRef] [PubMed]

90. Vaclavikova, M.; Matik, M.; Jakabsky, S.; Hredzak, S. Preparation and sorption properties of Fe-nanomaterials for removal of arsenic from waters. In Book of Abstract of NATO CCMS on Clean Products and Processes; NATO: Lillehammer, Norway, $2005 ;$ p. 13.

91. Hlavay, J.; Polyak, K. Determination of surface properties of ironhydrocide-coated alumina adsorbent prepared for removal of arsenic from drinking water. J. Colloid Interface Sci. 2005, 284, 71-77. [CrossRef]

92. Jekel, M. Removal of arsenic in drinking water treatment. In Arsenic in the Environment. Part I: Cycling and Characterization; Nriagu, J.O., Ed.; Wiley: New York, NY, USA, 1994; p. 119.

93. Rau, I.; Gonzalo, A.; Valiente, M. Arsenic(V) adsorption by immobilized iron mediation. Modeling of the adsorption process and influence of interfering anions. React. Funct. Polym. 2003, 54, 85-94. [CrossRef]

94. Ning, R.Y. Arsenic removal by reverse osmosis. Desalination 2002, 143, 237-241. [CrossRef]

95. Kang, M.; Kawasaki, M.; Tamada, S.; Kamei, T.; Magara, Y. Effect of pH on the removal of arsenic and antimony using reverse osmosis membranes. Desalination 2000, 131, 293-298. [CrossRef]

96. Kundu, S.; Gupta, A. Analysis and modeling of fixed bed column operations on As(V) removal by adsorption onto iron oxide-coated cement (I0CC). J. Colloid Interface Sci. 2005, 290, 52-60. [CrossRef]

97. Manna, A.K.; Sen, M.; Martin, A.R.; Pal, P. Removal of arsenic from contaminated groundwater by solar-driven membrane distillation. Environ. Pollut. 2010, 158, 805-811. [CrossRef]

98. Yarlagadda, S.; Gude, V.G.; Camacho, L.M.; Pinappu, S.; Deng, S. Potable water recovery from As, U, and F contaminated ground waters by direct contact membrane distillation process. J. Hazard. Mater. 2011, 192, 1388-1394. [CrossRef]

99. Hasan, H.A.; Muhammad, M.H.; Ismail, N.I. A review of biological drinking water treatment technologies for contaminants removal from polluted water resources. J. Water Process Eng. 2020, 33, 101035. [CrossRef]

100. Wang, S.; Zhao, X. On the potential of biological treatment for arsenic contaminated soils and groundwater. J. Environ. Manag. 2009, 90, 2367-2376. [CrossRef]

101. Mazumder, P.; Sharma, S.K.; Taki, K.; Kalamdhad, A.S.; Kumar, M. Microbes involved in arsenic mobilization and respiration: A review on isolation, identification, isolates and implications. Environ. Geochem. Health 2020, 42, 3443-3469. [CrossRef]

102. Han, B.; Runnels, T.; Zimbron, J.; Wickamasinghe, R. Arsenic removal from drinking water by floculation and microfiltration. Desalination 2002, 145, 293-298. [CrossRef]

103. Kumar, P.R.; Chaudhari, S.; Khilar, K.C.; Mahajan, S. Removal of arsenic from water by electrocoagulation. Chemosphere 2004, 55, 1245-1252. [CrossRef]

104. Dutta, A.; Chaudhuri, M. Removal of arsenic from ground water by lime softening with powdered coal additive. J. Water SRT-Aqua. 1991, 40, 25-29.

105. Petrusevski, B.; Sharma, S.K.; Schippers, J.C. Groundwater Treatment. Part II, UNESCO-IHE Lecture Notes; UNESCO: Delft, The Netherlands, 2003.

106. Schippers, J.C. Surface Water Treatment, UNESCO-IHE Lectures Notes; UNESCO: Delft, The Netherlands, 2003.

107. US-EPA Office of Ground Water and Drinking Water. Implementation Guidance for the Arsenic Rule; EPA report-816-D-02-005; EPA: Cincinnati, OH, USA, 2002.

108. Siddique, T.A.; Dutta, N.K.; Choudhury, N.R. Nanofiltration for arsenic removal: Challenges, recent developments, and perspectives. Nanomaterials 2020, 10, 1323. [CrossRef] [PubMed]

109. Xu, Y.; Nakajima, T.; Ohki, A. Adsorption and removal of arsenic (V) from drinking water by aluminium loaded Shirazuzeolite. J. Hazard. Mater. B 2002, 92, 275-278. [CrossRef] 
110. Vigneswaran, S.; Nguyen, T.V. Water Filtration System Wins $\$ 500 \mathrm{k}$ Technology Against Poverty Prize. School of Environmental and Environmental Engineering, UTS. 2017. Available online: https:/ /www.ecovoice.com.au/uts-water-filtration-system-winstechnology-against-poverty-500k-prize/ (accessed on 15 December 2017).

111. Deliyanni, E.; Bakoyannakis, D.; Zouboulis, A.; Matis, K. Sorption of As(V) ions by akaganéite-type nanocrystals. Chemosphere 2003, 50, 155-163. [CrossRef]

112. Matis, K.A.; Lehmann, M.; Zouboulis, A.I. Modelling sorption of metals from aqueous solution onto mineral particles: The case of arsenic ions and goethite ore. In Natural Microporous Materials in Environmental Technology; Springer International Publishing: New York, NY, USA, 1999; pp. 463-472.

113. Badruzzaman, M.; Westerhoff, P.; Knappe, D.R. Intraparticle diffusion and adsorption of arsenate onto granular ferric hydroxide (GFH). Water Res. 2004, 38, 4002-4012. [CrossRef] [PubMed]

114. Sperlich, A.; Werner, A.; Genz, A.; Amy, C.; Worch, E.; Jekel, I. Breakthrongh behavior of granular ferric hydroxide (C PH) fixedbed adsorption filters: Modeling and experimental approaches. Water Res. 2005, 39, 1190-1198. [CrossRef]

115. Zhang, W.; Singh, P.; Paling, E.; Delides, S. Arsenic removal from contaminated water by natural iron ores. Miner. Eng. 2004, 17, 517-524. [CrossRef]

116. Asere, T.G.; Stevens, C.V.; Du Laing, G. Use of (modified) natural adsorbents for arsenic remediation: A review. Sci. Total Environ. 2019, 676, 706-720. [CrossRef]

117. Singh, T.S.; Pant, K. Equilibrium, kinetics and thermodynamic studies for adsorption of As(III) on activated alumina. Sep. Purif. Technol. 2004, 36, 139-147. [CrossRef]

118. Manju, G.; Raji, C.; Anirudhan, T. Evaluation of coconut husk carbon for the removal of As from water. Water Res. 1998, 32, 3062-3070. [CrossRef]

119. Pattanayak, J.; Mondal, K.; Mathew, S.; Lalvani, S. A parametric evaluation of the removal of As(V) and As(III) by carbon-based adsorbents. Carbon 2000, 38, 589-596. [CrossRef]

120. Bertocchi, A.F.; Ghiani, M.; Peretti, R.; Zucca, A. Red mud and fly ash for remediation of mine sites contaminated with As, Cd, $\mathrm{Cu}, \mathrm{Pb}$ and Zn. J. Hazard. Mater. 2006, 134, 112-119. [CrossRef]

121. Demarco, M.J.; Sengupta, A.K.; Greenleaf, J.E. Arsenic removal using a polymeric/inorganic hybrid sorbent. Water Res. 2003, 37, 164-176. [CrossRef]

122. Genç-Fuhrman, H.; Bregnhøj, H.; McConchie, D. Arsenate removal from water using sand-red mud columns. Water Res. 2005, 39, 2944-2954. [CrossRef]

123. Altundoğan, H.; Altundoğan, S.; Tümen, F.; Bildik, M. Arsenic adsorption from aqueous solutions by activated red mud. Waste Manag. 2002, 22, 357-363. [CrossRef]

124. Dutta, P.K.; Ray, A.K.; Sharma, V.K.; Millero, F.J. Adsorption of arsenate and arsenite on titanium dioxide suspensions. J. Colloid Interface Sci. 2004, 278, 270-275. [CrossRef] [PubMed]

125. Jing, C.; Meng, X.; Liu, S.; Baidas, S.; Patraju, R.; Christodoulatus, C.; Korfiatis, C. Surface complexation of organic arsenic on nanocrystalline titanium dioxide. J. Colloid Interface Sci. 2005, 290, 14-21. [CrossRef] [PubMed]

126. Deschamps, E.; Ciminelli, V.S.; Höll, W.H. Removal of As(III) and As(V) from water using a natural Fe and Mn enriched sample. Water Res. 2005, 39, 5212-5220. [CrossRef]

127. Lenoble, V.; Laclautre, C.; Serpaud, B.; Deluchat, V.; Bollinger, J.-C. As(V) retention and As(III) simultaneous oxidation and removal on a $\mathrm{MnO}_{2}$-loaded polystyrene resin. Sci. Total Environ. 2004, 326, 197-207. [CrossRef]

128. Ghimire, K.; Inoue, K.; Yamaguchi, H.; Makino, K.; Miyajima, T. Adsorptive separation of arsenate and arsenite anions from aqueous medium by using orange waste. Water Res. 2003, 34, 4945-4953. [CrossRef]

129. Loukidou, M.; Matis, K.; Zouboulls, A.; Liakopoulou-Kyriakidou, M. Removal of As(V) from wastewaters by chemically modified fungal biomass. Water Res. 2003, 37, 4544-4552. [CrossRef]

130. Maiti, A.; Thakur, B.K.; Basu, J.K.; De, S. Comparison of treated laterite as arsenic adsorbent from different locations and performance of best filter under field conditions. J. Hazard. Mater. 2013, 262, 1176-1186. [CrossRef] [PubMed]

131. Thirunavukkarasu, O.S.; Viraraghavan, T.; Subramanian, K.S. Arsenic removal from drinking water using iron oxide-coated sand. Water Air Soil Pollut. 2003, 142, 95-111. [CrossRef]

132. Sahira Joshi, S.; Sharma, M.; Kumari, A.; Surendra Shrestha, S.; Shrestha, B. Arsenic removal from water by adsorption onto iron oxide/nano-porous carbon magnetic composite. Appl. Sci. 2019, 9, 3732. [CrossRef]

133. Zeng, L. A method for preparing silica-containing iron(III) oxide adsorbents for arsenic removal. Water Res. 2003, 37, 4351-4358. [CrossRef]

134. Mamindy-Pajany, Y.; Hurel, C.; Marmier, N.; Roméo, M. Arsenic adsorption onto hematite and goethite. Comptes Rendus Chim. 2009, 12, 876-881. [CrossRef]

135. Omeroglu, P. Use of Iron Coated Sand for Arsenic Removal. M.Sc. Thesis, SEE 131, UNESCO-IHE, Delft, The Netherlands, 2001.

136. Mondal, P.; Bhowmick, S.; Chatterjee, D.; Figoli, A.; Van der Bruggen, B. Remediation of inorganic arsenic in groundwater for safe water supply: A critical assessment of technological solutions. Chemosphere 2013, 92, 157-170. [CrossRef]

137. Hristovski, K.; Baumgardner, A.; Westerhoff, P. Selecting metal oxide nanomaterials for arsenic removal in fixed bed columns: From nanopowders to aggregated nanoparticle media. J. Hazard. Mater. 2007, 147, 265-274. [CrossRef]

138. Maiti, A.; Mishra, S.; Chaudhary, M. Nanoscale materials for arsenic removal from water. In Nanoscale Materials in Water Purification; Elsevier BV: Amsterdam, The Netherlands, 2019; pp. 707-733. 
139. Habuda-Stanić, M.; Nujić, M. Arsenic removal by nanoparticles: A review. Environ. Sci. Pollut. Res. 2015, $22,8094-8123$. [CrossRef]

140. Wong, W.; Wong, H.Y.; Badruzzaman, A.B.M.; Goh, H.H.; Zaman, M. Recent advances in exploitation of nanomaterial for arsenic removal from water: A review. Nanotechnology 2016, 28, 042001. [CrossRef]

141. Hua, M.; Zhang, S.; Pan, B.; Zhang, W.; Lv, L.; Zhang, Q. Heavy metal removal from water/wastewater by nanosized metal oxides: A review. J. Hazard. Mater. 2012, 211-212, 317-331. [CrossRef]

142. Qu, X.; Alvarez, P.J.; Li, Q. Applications of nanotechnology in water and wastewater treatment. Water Res. 2013, 47, 3931-3946. [CrossRef]

143. Tang, S.C.N.; Lo, I.M.C. Magnetic nanoparticles: Essential factors for sustainable environmental applications. Water Res. 2013, 47, 2613-2632. [CrossRef] [PubMed]

144. Kanel, S.R.; Manning, B.; Charlet, L.; Choi, H. Removal of arsenic(III) from groundwater by nanoscale zero-valent iron. Environ. Sci. Technol. 2005, 39, 1291-1298. [CrossRef]

145. Jegadeesan, G.; Mondal, K.; Lalvani, S.B. Arsenate remediation using nanosized modified zerovalent iron particles. Environ. Prog. 2005, 24, 289-296. [CrossRef]

146. Attinti, R.; Sarkar, D.; Barrett, K.R.; Datta, R. Adsorption of arsenic(V) from aqueous solutions by goethite/silica nanocomposite. Int. J. Environ. Sci. Technol. 2015, 12, 3905-3914. [CrossRef]

147. Adegoke, H.I.; Adekola, F.A.; Fatoki, O.S.; Ximba, B.J. A comparative study of sorption of As (V) ions on nanoparticle hematite, goethite and magnetite. Nanotechnology 2014, 1, 184-187.

148. Ramos, M.A.V.; Yan, W.; Li, X.-Q.; Koel, B.E.; Zhang, W.-X. Simultaneous oxidation and reduction of arsenic by zero-valent Iron nanoparticles: Understanding the significance of the core-shell structure. J. Phys. Chem. C 2009, 113, 14591-14594. [CrossRef]

149. Litter, M.I.; Morgada, M.E.; Bundschuh, J. Possible treatments for arsenic removal in Latin American waters for human consumption. Environ. Pollut. 2010, 158, 1105-1118. [CrossRef]

150. Tang, W.; Li, Q.; Gao, S.; Shang, J.K. Arsenic(III,V) removal from aqueous solution by ultrafine $\alpha-\mathrm{Fe}_{2} \mathrm{O}_{3}$ nanoparticles synthesized from solvent thermal method. J. Hazard. Mater. 2011, 192, 131-138. [CrossRef] [PubMed]

151. Chowdhury, S.R.; Yanful, E.K. Arsenic removal from aqueous solutions by adsorption on magnetite nanoparticles. Water Environ. J. 2010, 25, 429-437. [CrossRef]

152. Pena, M.E.; Korfiatis, G.P.; Patel, M.; Lippincott, L.; Meng, X. Adsorption of As(V) and As(III) by nanocrystalline titanium dioxide. Water Res. 2005, 39, 2327-2337. [CrossRef]

153. Jegadeesan, G.; Al-Abed, S.R.; Sundaram, V.; Choi, H.; Scheckel, K.G.; Dionysiou, D.D. Arsenic sorption on $\mathrm{TiO}_{2}$ nanoparticles: Size and crystallinity effects. Water Res. 2010, 44, 965-973. [CrossRef]

154. Nabi, D.; Aslam, I.; Qazi, I.A. Evaluation of the adsorption potential of titanium dioxide nanoparticles for arsenic removal. J. Environ. Sci. 2009, 21, 402-408. [CrossRef]

155. Ashraf, S.; Siddiqa, A.; Shahida, S.; Qaisar, S. Titanium-based nanocomposite materials for arsenic removal from water: A review. Heliyon 2019, 5, e01577. [CrossRef]

156. Guan, X.; Du, J.; Meng, X.; Sun, Y.; Sun, B.; Hu, Q. Application of titanium dioxide in arsenic removal from water: A review. J. Hazard. Mater. 2012, 215-216, 1-16. [CrossRef] [PubMed]

157. Xu, Z.; Li, Q.; Gao, S.; Shang, J.K. As(III) removal by hydrous titanium dioxide prepared from one-step hydrolysis of aqueous $\mathrm{TiCl}_{4}$ solution. Water Res. 2010, 44, 5713-5721. [CrossRef] [PubMed]

158. Hussam, A.; Munir, A.K.M. A simple and effective arsenic filter based on composite iron matrix: Development and deployment studies for groundwater of Bangladesh. J. Environ. Sci. Health Part A 2007, 42, 1869-1878. [CrossRef] [PubMed]

159. Gianotti, R. Filtering Out Arsenic in Nepal; MIT Komaza Magazine: Cambridge, MA, USA, 2011; pp. 17-19.

160. Ngai, T.K.; Shrestha, R.R.; Dangol, B.; Maharjan, M.; Murcott, S.E. Design for sustainable development-Household drinking water filter for arsenic and pathogen treatment in Nepal. J. Environ. Sci. Health Part A 2007, 42, 1879-1888. [CrossRef]

161. Singh, A.; Smith, L.S.; Shrestha, S.; Maden, N. Efficacy of arsenic filtration by kanchan arsenic filter in Nepal. J. Water Health 2014, 12, 596-599. [CrossRef]

162. Hayder, S.; Ahmed, T.; Tariq, M. Arsenic: A low-cost household level treatment for rural settings in developing countries. J. Pollut. Eff. Control. 2018, 6, 1-5. [CrossRef]

163. Naus, F.L.; Burer, K.; Van Laerhoven, F.; Griffioen, J.; Ahmed, K.M.; Schot, P. Why do people remain attached to unsafe drinking water options? Quantitative evidence from Southwestern Bangladesh. Water 2020, 12, 342. [CrossRef]

164. Das, J.; Sarkar, P.; Panda, J.; Pal, P. Low-cost field test kits for arsenic detection in water. J. Environ. Sci. Health Part A 2013, 49 , 108-115. [CrossRef] [PubMed]

165. Industrial Test Systems Quick 481396-5 Arsenic for Water Quality Testing. Available online: https://www.amazon.com/ Industrial-Test-Systems-481396-5-Arsenic/dp/B07V9C3W5Y (accessed on 18 January 2021).

166. Vitasalus Inc., Troy, MI, USA. Available online: http: / / www.equinox-products.com/ArsenicMaster.htm (accessed on 20 December 2020). 